\title{
Interannual response of global ocean hindcasts to a satellite-based correction of precipitation fluxes
}

\author{
A. Storto ${ }^{1}$, I. Russo ${ }^{1}$, and S. Masina ${ }^{1,2}$ \\ ${ }^{1}$ Centro Euro-Mediterraneo per i Cambiamenti Climatici, viale A. Moro 44, 40127 Bologna, \\ Italy \\ ${ }^{2}$ Istituto Nazionale di Geofisica e Vulcanologia, Bologna, Italy
}

Received: 27 January 2012 - Accepted: 2 February 2012 - Published: 10 February 2012

Correspondence to: A. Storto (andrea.storto@cmcc.it)

Published by Copernicus Publications on behalf of the European Geosciences Union.

\section{A satellite-based correction of precipitation fluxes}

\section{A. Storto et al.}

\section{Title Page}

\section{Abstract}

Conclusions

Tables

References

Figures

14

4

Back

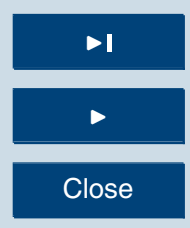

Full Screen / Esc

Printer-friendly Version

Interactive Discussion 


\section{Abstract}

We present a methodology to correct precipitation fluxes from the ECMWF atmospheric reanalysis (ERA-Interim) for oceanographic applications. The correction is performed by means of a spatially varying monthly climatological coefficient, computed within the 5 period 1989-2008 by comparison between ERA-Interim and a satellite-based passive microwave precipitation product. ERA-Interim exhibits a systematic over-estimation of precipitation within the inter-tropical convergence zones (up to $3 \mathrm{~mm} \mathrm{~d}^{-1}$ ) and underestimation at mid- and high- latitudes (up to $-4 \mathrm{~mm} \mathrm{~d}^{-1}$ ). The correction has been validated within eddy-permitting resolution global ocean hindcasts (1989-2009), demonimbalance by $16 \%$, reducing the near-surface salinity fresh bias in the Tropics up to 1 psu and improving the representation of the sea level interannual variability, with an $\mathrm{SSH}$ error decrease of $8 \%$. The ocean circulation is also proved to benefit from the correction, especially in correspondence of the Antarctic Circumpolar Current, where 15 the error in the near-surface current speed decreases by a $9 \%$. Finally, we show that the correction leads to volume and freshwater transports that better agree with independent estimates.

\section{Introduction}

The correct estimation of the amount of air-sea freshwater exchange and its spatial 20

variability has a great importance in Ocean General Circulation Model (OGCM) simulations, as this directly affects the sea-surface salinity and the eustatic component of the sea level, and plays an important role in the ocean baroclinic and barotropic circulation (Huang and Schmitt, 1993). For instance, in semi-enclosed basins and shallow waters, due to their dynamics, the balance and distribution of freshwater fluxes dramatically the Intertropical Convergence Zone, where the freshwater flux variability is maximum (Ponte, 2006).

OSD

$9,611-648,2012$

\section{A satellite-based correction of precipitation fluxes}

A. Storto et al.

\section{Title Page}

Abstract

\section{Full Screen / Esc}

Printer-friendly Version

Interactive Discussion 
Usually, oceanographers delegate the atmospheric models to provide precipitation flux estimates, in both operational (e.g., Dombrowsky et al., 2009) and reanalysis (e.g., Masina et al., 2011) contexts, since this is the simplest way to have a dataset with regular spatial coverage and temporal frequency. However, many studies (see for in5 stance Stendel and Arpe, 1997; Janowiak et al., 1998; Arpe et al., 2000; Janowiak et al., 2010) have compared reanalysis and atmospheric model precipitation fields with observation-based dataset, and have shown that atmospheric model products always bring significant and systematic errors, and are not able to close the freshwater budget. For instance, Janowiak et al. (2010) found that the European Centre for Medium-range 10 Weather Forecasts (ECMWF) ERA-Interim reanalysis (Simmons et al., 2007) shows a good temporal variability with respect to observational datasets, although it globally overestimates the daily precipitation.

The proper representation of the water fluxes in ocean models is complicated by the fact that OGCMs usually force the globally-averaged value of evaporation minus 15 precipitation minus continental runoff (EMP) to be zero within a certain time interval, in order to avoid unrealistic drifts of the global spatial average of sea level, which certainly would occur and would make infeasible the monitoring of such a climate change keyparameter. To exemplify, a global negative imbalance of $-0.26 \mathrm{~Sv}\left(1 \mathrm{~Sv}=10^{6} \mathrm{~m}^{3}\right)$ in the EMP (found for ERA-Interim over the period 1989-2009 and using the Dai and 20 Trenberth (2002) continental runoff climatology) would lead to an unrealistic sea level rise of $2.2 \mathrm{~cm} \mathrm{yr}^{-1}$, which is more than ten times larger than the value suggested by Cazenave et al. (2009) for the contributions of land ice and land waters to the global sea level rise within the period 2003-2008. Furthermore, zeroing the global spatial average of the EMP implies that a wrong specification of precipitation fields has not solely a local effect but may also affect remote regions.

The correction of atmospheric forcing within ocean applications has already been successfully explored by adjusting atmospheric fluxes via observational dataset in both global (Large and Yeager, 2009) and regional (Pettenuzzo et al., 2010) applications. Another emerging approach consists in an advanced use of ocean data assimilation
OSD

$9,611-648,2012$

\section{A satellite-based correction of precipitation fluxes}

A. Storto et al.

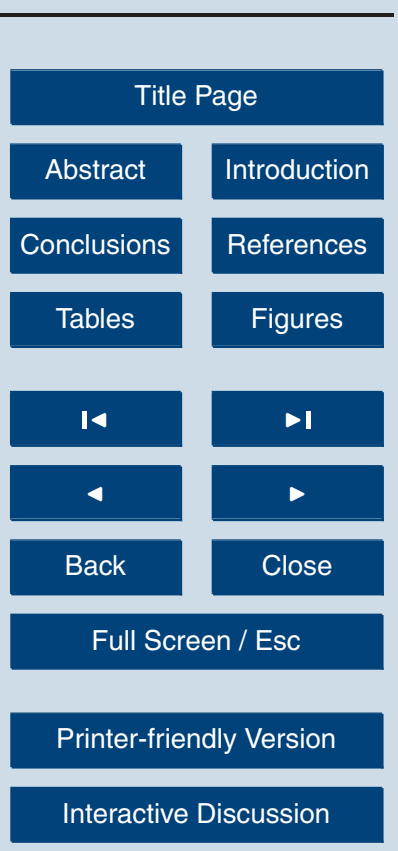


procedure to correct air-sea fluxes (Stammer et al., 2004). Bias-correction methodologies specifically developed over the recent years to adjust modelled precipitation generally rely on in-situ (i.e. rain gauges) measurement calibration (see e.g., Yang et al., 2005), and are useless in the context of global ocean applications due to the very poor 5 and coastal only coverage of these observations in the oceans. Conversely, principal component analysis methods (Feudale and Tompkins, 2011) have been used to recover from systematic spatial errors that are typical of seasonal forecasting systems and arise, for instance, from the low predictability in the Tropics.

In this paper we evaluate the impact of an empirical correction procedure based 10 on the comparison between the ERA-Interim precipitation and the Remote Sensing Systems Passive Microwave Water Cycle precipitation product (Hilburn, 2009). This dataset was chosen i) because of its higher spatial resolution $\left(1 / 4^{\circ}\right)$ with respect to the more popular GPCP dataset (Huffman et al., 2009), despite its lower temporal resolution (monthly), which is however less crucial for a climatological correction as ours and ii) because PMWC aims at closing the atmospheric hydrological cycle, unlike other datasets, providing also estimates of evaporation and moisture transports. In the same way as many similar studies that aim to assess the variations of the state of the ocean due to a change in the freshwater income (see for instance Marsh et al., 2010), we evaluate the impact of the correction by studying the relative differences between the experiment with and without the correction and validating the correction against independent observational datasets.

The paper is organized as follows: Sect. 2 explains the methodology and describes the data used to correct the precipitation fluxes; Sect. 3 briefly reviews the global ocean model configuration, while Sect. 4 contains the impact assessment results and Sect. 5 discusses the main achievements. Although the final goal is to introduce the correction in the Centro Euro-Mediterraneo per i Cambiamenti Climatici (CMCC) reanalysis system (Masina et al., 2011; Storto et al., 2011) where the correction is being implemented, the impact is evaluated here within assimilation-blind experiments for sake of simplicity and also to evaluate the impact with completely independent verifying
OSD

9, 611-648, 2012

\section{A satellite-based correction of precipitation fluxes}

A. Storto et al.

Title Page

Abstract Introduction

Conclusions

Tables References Figures

14

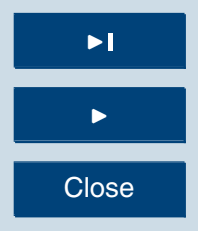

Back

Close

Printer-friendly Version

Interactive Discussion 


\section{Correction of precipitation}

The proposed method consists of correcting the daily precipitation fluxes by means of a monthly climatological coefficient, inferred from the comparison between the PMWC 5 and the ERA-Interim precipitation.

The satellite-based Passive Microwave Water Cycle (PMWC) dataset is produced by Remote Sensing Systems (REMSS) in the frame of the NASA (National Aeronautics and Space Administration) Energy and Water Cycle Study (Hilburn, 2009). PMWC data of precipitation are essentially rain rate retrievals from the instruments Special Sensor 10 Microwave/Imager (SSM/I) on board the satellites of the United States Air Force Defense Meteorological Satellite Program (DMSP). The retrieval algorithm is described by Hilburn and Wentz (2008). Data over high-latitude regions are subjected to snow adjustments, based on the comparison between uncorrected PMWC and total precipitation rates from the Global Precipitation Climatology Project (GPCP, Huffman et al., 15 2009). The spatial resolution of $P M W C$ is $0.25^{\circ}$ on both zonal and meridional directions. The 1989-2008 precipitation rate bias between ERA-Interim and PMWC is shown in Fig. 1: the bias is positive between $20^{\circ} \mathrm{S}$ and $20^{\circ} \mathrm{N}$ in agreement with the comparison of Janowiak et al. (2010). The highest positive biases are found in the western tropical regions, where the zonally averaged bias of ERA-Interim is of about $1.8 \mathrm{~mm} \mathrm{~d}^{-1}$ and peaks around the Indonesian Throughflow and the Western Tropical Atlantic at values of about $3 \mathrm{~mm} \mathrm{~d}^{-1}$. Except in the South Pacific, the bias turns to negative at mid- and high-latitudes, especially in the western boundaries of the Northern Hemisphere (Gulf Stream and Kuroshio regions) and in the South Atlantic. The negative bias is more evident than in Janowiak et al. (2010) and peaks in the Gulf Stream region at about 25 $-4 \mathrm{~mm} \mathrm{~d}^{-1}$. The inter-annual variability of precipitation (not shown) reveals that ERAInterim agrees very well with microwave data in the Extra-Tropics (the correlation for the 1989-2008 period is 0.86 and 0.90 in the Southern and Northern Extra-Tropics,
$9,611-648,2012$

\section{A satellite-based correction of precipitation fluxes}

A. Storto et al.

Title Page

Abstract Introduction

Conclusions

Tables

References

Figures

14

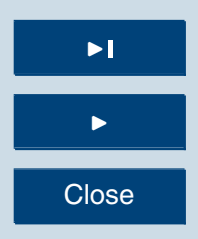

Back

Close

Full Screen / Esc

Printer-friendly Version

Interactive Discussion 
respectively, with a very small bias less than $0.1 \mathrm{~mm} \mathrm{~d}^{-1}$ in both regions) while in the Tropics the correlation drops to 0.49 with a systematic positive bias of $1.2 \mathrm{~mm} \mathrm{~d}^{-1}$.

The use of a climatological corrective factor - instead of the direct use of PMWC data - stems from the fact that these data are available as monthly means. Such a temporal 5 resolution could jeopardise the representation of any intra-seasonal variability of the EMP, as well as the potential applicability in an operational framework. Furthermore, the use of a climatological corrective factor allows us to apply the correction to any period also prior to the SSM/I era. Note also that the correction, by construction, does not alter the inter-annual variability of the precipitation forcing.

$$
c=\left\langle 10^{3} \frac{\exp \left(P_{M}^{\mathrm{LS}}\right)}{\exp \left(P_{E}^{\mathrm{LS}}\right)}-10^{3}\right\rangle_{1989-2008}
$$

where $P_{M}^{\mathrm{LS}}$ and $P_{E}^{\mathrm{LS}}$ are the large-scale precipitation values from REMSS/PMWC and ECMWF/ERA-Interim, respectively, and $\langle\ldots\rangle_{1989-2008}$ denotes the temporal mean over the period 1989-2008. $\quad c$ is spatially-varying and computed at the full model hori-

zontal resolution (both ERA-Interim and PMWC fields are interpolated on the ocean model grid); the value $10^{3}$ has the meaning of a normalization factor. The formulation of Eq. (1) is arbitrary: the ratio of the exponential was preferred to the simple ratio (as in Large and Yeager, 2009) to avoid discontinuities when either REMSS/PMWC or ECMWF/ERA-Interim exhibits zero precipitation. In order to use the corrective coefficient within the mass and salt flux surface boundary conditions during the ocean model integration, the daily-corrected values $P$ are then recalibrated, in accordance with Eq. (1), as:

$P=P_{E}^{\mathrm{SS}}+\log \left[\left\{10^{-3}\left(10^{3}+c\right)\right\} \exp \left(P_{E}^{\mathrm{LS}}\right)\right]$

where the upper-script $S S$ stands for small-scale. In both Eqs. (1) and (2) the sep-

aration between small and large scales is obtained through the application of a two-
OSD

$9,611-648,2012$

\section{A satellite-based correction of precipitation fluxes}

A. Storto et al.

\section{Title Page}

Abstract

\section{Full Screen / Esc}

Printer-friendly Version

Interactive Discussion 
dimensional low-pass Shapiro filter, tuned to have $20 \%$ amplitude attenuation at the spatial scales corresponding to $900 \mathrm{~km}$. The low-pass filter was applied in an attempt of neglecting precipitation location error and consistently with similar experiences in the global ocean modelling community (e.g., Garric et al., 2011), which enlighten the 5 importance of keeping the small-scale signals from the high-resolution atmospheric forcing. In applying Eq. (2), the monthly corrective coefficient of Eq. (1) is linearly interpolated in time to provide daily values.

In Fig. 2, contours of the precipitation corrective coefficient are shown as a function of latitude and month. A value of zero means that there is no correction, while positive 10 (negative) values indicate that ERA-Interim underestimates (overestimates) the precipitation with respect to the satellite-based precipitation. The northward drift of the bias visible in Fig. 2 from January to August seems to be related to the seasonal displacement of the Inter-Tropical Convergence Zones (ITCZs). The zonal averages show that the precipitation is enforced more in the Arctic than in the Antarctic, and maxima of the

\section{Ocean model description}

The OGCM used in this study is the version 3.2 of NEMO (Nucleus for European Modelling of the Ocean, Madec, 2008) in ORCA025-L50 configuration, coupled to the Louvain-la-Neuve sea-ice model (LIM2, Fichefet and Morales Maqueda, 1997). The 20 model has an irregular tripolar grid with $1 / 4^{\circ}$ of horizontal resolution, constant in the zonal direction and increasing poleward in the meridional direction, and 50 vertical levels with partial steps at the bottom.

The experiments consist of a 21-yr (1989-2009) simulation initialized with a 5-yr climatological spinup. The spinup started from rest and from Levitus et al. (1998) monthly climatology of temperature and salinity fields. The National Snow and Ice Data Centre provided the sea-ice initial parameters. The simulation has been performed with the Coordinated Ocean-ice Reference Experiment (CORE) bulk-formulas forcing

\section{OSD}

$9,611-648,2012$

\section{A satellite-based correction of precipitation fluxes}

A. Storto et al.

\section{Title Page}

\section{Full Screen / Esc}

Printer-friendly Version

Interactive Discussion 
method (Large and Yeager, 2009) and using 6-hourly ERA-Interim (Simmons et al., 2007) turbulent and radiative fluxes and daily freshwater fluxes of precipitation and snow. The runoff dataset is a monthly climatology that includes 99 major rivers and coastal runoffs (Bourdalle-Badie and Treguier, 2006).

5 Several corrections have been applied to the forcing fields in order to improve the model representation of the ocean state. Large-scale downward short-wave and longwave radiation fluxes have been corrected by means of a large-scale climatological correction coefficient derived by the Global Energy and Water Cycle Experiment (GEWEX) Surface Radiation Budget project (Garric et al., 2011). Wind stress magnitude has 10 been adjusted by means of a climatological correction coefficient derived by the SCOW (Scatterometer Climatology of Ocean Winds) QuickScat monthly climatology (Risien and Chelton, 2008). Furthermore, as previously explained in the Introduction, the global average of evaporation minus precipitation minus runoff has been forced to be equal to zero at each model time-step.

15 Concerning the physics of the model, the Turbolent Eddy Kinetic (TKE) dependent vertical diffusion scheme has been used to compute the eddy vertical mixing coefficient. The vertical parametrizations include: (i) the Enhanced Vertical Diffusion (EVD) scheme; (ii) double diffusion mixing parametrization for temperature and salinity; (iii) a mixing length scale surface value as function of wind stress. For the lateral dynam20 ics of tracers, we used the Total Variation Diminishing (TVD) advection scheme and a laplacian isopycnal diffusion scheme for lateral diffusion. A bilaplacian operator has been used for lateral viscosity of momentum.

\section{Impact on ocean state and variability}

\subsection{Impact on global freshwater budget}

25 Correcting the precipitation fluxes determines an immediate change in the global ocean freshwater budget. This is shown in terms of globally-averaged components of the
OSD

$9,611-648,2012$

\section{A satellite-based correction of precipitation fluxes}

A. Storto et al.

\section{Title Page}

Abstract

\section{Full Screen / Esc}

Printer-friendly Version

Interactive Discussion

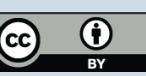


freshwater balance in Table 1, in terms of time-mean, trend, annual and semi-annual amplitudes, the latter obtained through fitting the global timeseries to a periodic function with both annual (12-month periodic) and semi-annual (6-month periodic) terms, for both the experiments with and without the precipitation correction. As mentioned 5 in Sect. 3, the river and ice-sheet runoff is provided by a monthly climatology, with a year-mean value equal to $1.309 \mathrm{~Sv}$, a maximum in June (1.834 Sv) and a minimum in November (1.071 Sv).

The globally averaged time-mean precipitation flux varies from 13.530 to $13.487 \mathrm{~Sv}$ by applying the correction, with a net decrease of $0.044 \mathrm{~Sv}$. The evaporation flux 10 change was indeed found negligible between the two experiments, and equal to about $14.58 \mathrm{~Sv}$. Note that all the terms of the global freshwater fluxes are overestimated with respect to some recent estimates. For instance, Lagerloef et al. (2010) provide values of $13,12.2$ and $0.8 \mathrm{~Sv}$ for evaporation, precipitation and runoff, respectively.

The global precipitation decrease is in turn directly brought into the EMP imbalance, 15 which slightly increases from -0.255 to $-0.215 \mathrm{~Sv}$, corresponding to a $15.7 \%$ imbalance reduction. These imbalances can be considered below the error bars of the freshwater fluxes estimation (Lagerloef et al., 2010). Nevertheless, they correspond to an equivalent sea level rise of 22.26 and $18.77 \mathrm{~mm} \mathrm{yr}^{-1}$, respectively, which are unreasonably large and require the artificial closure of the global EMP to avoid unrealistic 20 sea level drifts. Given that the overestimation of the precipitation peaks around April (Fig. 2), thus having a marked seasonal signal, the precipitation flux after the correction is consequently affected by larger seasonal amplitude $(0.484 \mathrm{~Sv})$ with respect to the uncorrected fluxes $(0.032 \mathrm{~Sv})$. Trend values are very small as expected, and enlighten the slight decrease of precipitation over the 1989-2009 period and the very small increase 25 of evaporation, which sum up to an EMP trend of the order of $0.03-0.04 \mathrm{~Sv} \mathrm{vr}^{-1}$.

To summarize, the correction contributes to mitigate the EMP negative imbalance, thus reducing the remote effect of the global zeroing of the EMP. However, this remains still large $(-0.215 \mathrm{~Sv})$ and the closure of the freshwater budget cannot be avoided in order to have realistic sea level trends. We believe that future improvements of the

\section{OSD}

$9,611-648,2012$

\section{A satellite-based correction of precipitation fluxes}

A. Storto et al.

\section{Title Page}


correction strategy should aim at reaching a negligible imbalance of the global EMP, thus withdrawing the superimposed closure of the EMP flux.

\subsection{Impact on sea- and sub- surface ocean salinity and temperature}

We evaluate the impact of the correction firstly on the main ocean parameters, and 5 secondly on some integrated quantities affected by the correction. Compared to the World Ocean Atlas 2009 salinity climatology (Antonov et al., 2010), the uncorrected precipitation leads to a fresh bias in the subtropical and, even larger, in the tropical sea surface salinity (SSS), as visible in Fig. 3. The bias peaks in the Western Tropical Pacific and Atlantic Oceans and in the Eastern Tropical Indian Ocean, where it reaches 10 values of the order of 1 to $2.3 \mathrm{psu}$. These biases are clearly reduced to values generally below 0.5 psu when the precipitation correction is applied. As also discussed later on, while the tropical fresh bias is a direct effect of the precipitation surplus, the fresh bias at the western subtropical regions depends on the gyre circulation that therein transports the overestimated freshwater coming from the Tropics. Note indeed that the 15 ERA-Interim precipitation fluxes exhibit a dry bias in the subtropical regions (Fig. 1). In the storm track regions of the North Atlantic and Pacific Oceans and in the Southern Hemisphere high latitudes, the SSS salty bias is of about 0.5 to $1 \mathrm{psu}$, and it is mitigated by the precipitation correction by a factor 2 .

The verification against the mooring arrays in the Pacific (TAO/TRITON), Indian 20 (RAMA) and Atlantic (PIRATA) Oceans shows consistent results (not shown): the seasurface fresh bias and root mean square error (RMSE) are reduced from about -0.5 to $0.1 \mathrm{psu}$ and from 0.9 to $0.5 \mathrm{psu}$, respectively. The mitigation of the fresh bias deepens up to $50 \mathrm{~m}$ of depth. Below, the correction leads to a slight salty bias ( $0.1 \mathrm{psu})$, whereas the experiment with uncorrected precipitation exhibits a smaller bias. This suggests 25 that the precipitation reduction is probably too strong in the Tropics and quickly mixes within the mixing layer. Below $200 \mathrm{~m}$ of depth, the correction seems to have no impact on salinity in the tropical regions. The study of the inter-annual variability (not shown) of the bias and RMSE shows that the correction becomes effective after about $1 \mathrm{yr}$ from the experiment start, and constantly moves the salinity bias closer to zero.

\section{OSD}

$9,611-648,2012$

\section{A satellite-based correction of precipitation fluxes}

A. Storto et al.

\section{Title Page}

\section{Full Screen / Esc}

Printer-friendly Version

Interactive Discussion 
No significant impact was found on sea- and sub- surface temperature skill scores, except for a positive contribution of the correction to a warm bias reduction - with respect to the climatology of the National Oceanic and Atmospheric Administration (NOAA) daily $1 / 4^{\circ}$ sea-surface temperature analyses - from about 1.5 to $1 \mathrm{~K}$ in cor5 respondence of the Amundsen Sea and in other areas of the Antarctic region (not shown).

\subsection{Impact on sea level variability}

The precipitation correction is expected to have a significant impact on the sea surface height, as it may modify both the barotropic (depth-independent) response of the ocean to the surface water mass fluxes and the sea level baroclinic component because of the changes in the upper ocean density. This in turn may induce many secondary effects due to both advection and diffusion. Furthermore, the artificial closure of the evaporation minus precipitation minus runoff balance, as mentioned previously, may also contribute to remote variations in the sea level, although, in the sequel, we will assume this remote effect to be negligible.

An important effect of the correction in the western boundaries of the Tropical Oceans is the corresponding sea level lowering of 5-7, 5-6 and 1-3cm in the Pacific, Indian and North Atlantic Oceans, respectively (visible in Fig. 4a), which might be due to the simultaneous effect of the barotropic response to the precipitation decrease and the tion. The precipitation correction is able to positively impact the sea-surface height skill scores, especially in correspondence of the Antarctic Circumpolar Current (ACC). In fact, we found a RMSE decrease of sea-surface height (SSH) fields verified against the AVISO sea level anomaly (SLA) monthly merged products. The decrease has reach $2 \mathrm{~cm}$ from $50^{\circ} \mathrm{S}$ to $45^{\circ} \mathrm{S}$ and local peaks of more than $20 \mathrm{~cm}$ in the South Pacific Ocean (Fig. 4b). Note that the comparison was performed by removing the globally averaged value of SSH from the AVISO monthly maps, in order to remove the time

OSD

9, 611-648, 2012

\section{A satellite-based correction of precipitation fluxes}

A. Storto et al.

\section{Title Page}

\section{Full Screen / Esc}

Printer-friendly Version

Interactive Discussion 
varying global steric (expansion/contraction) and eustatic (freshwater imbalance) variations of the Global Ocean measured by satellite altimetry, which are not accounted for by NEMO.

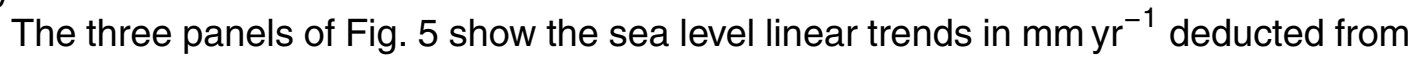
5 the altimetric observations and from the two experiments for the period 1993-2009. The use of the correction clearly improves the representation of the interannual sea level variability in many areas. In particular, the too high trends in the Western Pacific and in the Indian Ocean are mitigated by the correction; consequently, also the too negative trends found in the Atlantic and in the Southern Oceans increase their values 10 and better agree with the observed trends. Areas where the uncorrected water fluxes lead to very negative trends as east of South Brazil or southeast of New Zealand see a slight increase in the trends. In the verification against AVISO monthly products, the timeseries (Fig. 6) prove the benefits of the correction: compared to AVISO, the precipitation correction mitigates the too negative trend of $\mathrm{SSH}$ in correspondence of the 15 ACC and the South Atlantic, thus contributing to stabilizing the RMSE against AVISO SLA over the $1993-2009$ period for both the $60^{\circ} \mathrm{S}-60^{\circ} \mathrm{N}$ region and the Antarctic Circumpolar Current region (right panels of Fig. 6).

The impact of the correction on the sea level is however not straightforward to understand, as it arises from changes in both the barotropic and baroclinic components, which are hardly distinguishable by using monthly mean model outputs. Based on these limitations, it is however possible to quantify the main components of the sea level variability. Indeed, it is common practice to approximate the baroclinic component of sea level with the "dynamic height" (e.g., Lowe and Gregory, 2006; Dhomps et al., 2011):

${ }_{25} \quad \eta^{\mathrm{DH}}=-\frac{1}{\rho_{0}} \int_{-H_{0}}^{0}\left(\rho(T, S)-\rho_{0}\right) d z$
OSD

$9,611-648,2012$

\section{A satellite-based correction of precipitation fluxes}

A. Storto et al.

\section{Title Page}

\section{Full Screen / Esc}

Printer-friendly Version

Interactive Discussion 
where $\rho_{0}$ is a reference density $-\rho_{0}=\rho\left(T_{0}, S_{0}\right)$, where $T_{0}$ and $S_{0}$ are reference (i.e. climatological) temperature and salinity, respectively,$- H_{0}$ is the so-called "level of nomotion" where currents are assumed to be zero, which serves the purpose of calculating the sea level from the geostrophic balance without knowing the barotropic current 5 streamfunction (Pinardi et al., 1995).

The correlation of the differences between the dynamic heights of the two experiments with the differences between the model output SSH of the two experiments is shown in Fig. 7. The plot does not correlate the model SSH with its baroclinic signal which is known to be dominant everywhere except in the ACC and, to a lesser extent, 10 in subtropical gyre areas, see e.g., Pinardi et al. (1995) -, but only the differences, namely it provides an estimate of the degree of baroclinicity of the $\mathrm{SSH}$ anomalies induced by the precipitation correction. Note that, according to the one-sided t-Test for the correlation (as negative correlations are meaningless), the minimum significant correlation at $99 \%$ is equal to 0.162 . The figure reveals that in large areas of the Global Ocean the differences between the monthly SSH between the two experiments are well-correlated with the differences in the dynamic height of Eq. (3), suggesting that in those areas the SSH variability can be well explained by the variability in the baroclinic component of the sea level, either caused by the near-surface density changes or induced by baroclinic circulation adjustments. Furthermore, the areas where the correlation is found non-significant or small, which correspond to the Eastern Tropical Pacific and, to a lesser extent, to the Tropical Indian plus some areas in the Southern Ocean and in proximity of the Bering Strait, are suspected to receive a major effect of the barotropic response to the precipitation correction.

Equation (3) may be further decomposed in order to separately account for temper25 ature and salinity contributions to the dynamic height:

\section{OSD}

$9,611-648,2012$

\section{A satellite-based correction of precipitation fluxes}

A. Storto et al.

\section{Title Page}

\section{Full Screen / Esc}

Printer-friendly Version

Interactive Discussion 
$\eta^{\mathrm{DH}}=-\frac{1}{\rho_{0}} \int_{-H_{0}}^{0}\left(\rho\left(T, S_{0}\right)-\rho_{0}\right) d z-\frac{1}{\rho_{0}} \int_{-H_{0}}^{0}\left(\rho\left(T_{0}, S\right)-\rho_{0}\right) d z$

OSD

$9,611-648,2012$

$$
=\mathrm{DH}(T, S)=\mathrm{DH}\left(T, S_{0}\right)+\mathrm{DH}\left(T_{0}, S\right)
$$

where the latter notation is introduced for sake of simplicity. These are the thermal $5 \mathrm{DH}\left(T, S_{0}\right)$ - and haline - $\mathrm{DH}\left(T_{0}, S\right)$ - contributions to the baroclinic sea level.

By integrating the usual kinematic sea-surface condition (Beron-Vera et al., 1999) for sea level one obtains:

$\frac{\partial \eta}{\partial t}=-\nabla_{h} \cdot\left(\frac{1}{H} \int_{H}^{0} u d z\right)-\frac{E-P}{\rho_{\mathrm{f}}}$

where $H$ is the ocean depth, $\boldsymbol{u}$ is the horizontal current vector, $E$ and $P$ are the evap10 oration and precipitation fluxes, respectively, and $\rho_{\mathrm{f}}$ is the freshwater density. Such a formulation is actually used within the OGCM to prognose the sea level variations. The effect of the EMP on the barotropic (BT) component of sea level is then equal to:

$\eta_{\mathrm{EMP}}^{\mathrm{BT}}=-\int\left(\frac{E-P}{\rho_{\mathrm{f}}}\right) d t$

Equations (4) and (6) represent a simple diagnostic estimation of the EMP effects on the baroclinic and barotropic sea level variability, respectively. More sophisticate estimates may certainly be computed, but they would require extra output fields from the OGCM. By diagnosing the mixing layer salinity differences (between the two experiments) that are due only to the modified EMP diluting effect on the mixing layer salinity (following the approach of Lagerloef et al., 2010), we have found that such a contribution is much less important than the salinity differences induced by the advective effects, and therefore we will consider this effect negligible.

\section{A satellite-based correction of precipitation fluxes}

A. Storto et al.

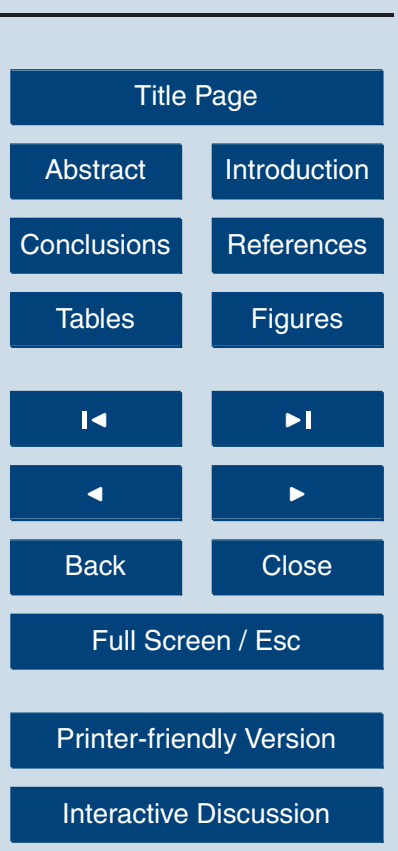

Interactive Discussion 
In order to appreciate the contributions of the sea level components introduced in this Section, we report them in Fig. 8 in terms of linear trends of the monthly differences between the two experiments (that with the correction minus that without). Doing this, we are able to comprehend the effects that lead to the SSH difference of Fig. 4a.

5 Trends are shown in millimetres per year. Firstly, it is important to note that barotropic response - the two right-hand side terms of Eq. (5) - is much larger than the baroclinic terms, as the sea level trend due to the freshwater change (Fig. 8e) and that due to the differences of the vertical integral of the horizontal divergence (Fig. 8f) balance each other and sum up to the model output SSH trend (Fig. 8a). Despite the different 10 timescale, summing the two components of Eq. (5) provides perfectly the total SSH difference and allows us to proceed further. These two components have values that peak around 1 meter per year. Therefore, the contribution from the barotropic EMP alone cannot be directly compared with the baroclinc components.

By comparing the SSH trend (Fig. 8a) with that given by the dynamic height equation 15 (Fig. 8b), it emerges that, as suggested by the correlation of Fig. 7, the baroclinic sea level is not responsible for the decrease of sea level in the Tropical regions $\left(20^{\circ} \mathrm{S}-\right.$ $20^{\circ} \mathrm{N}$ ) of the Indian and Pacific Oceans, which is consequently given by the barotropic response of the sea level. Elsewhere, the baroclinic sea level trend well approximates the SSH trend. Interestingly, we found that the haline contribution to the baroclinic sea level trend (Fig. 8c) is the major contributor of the $\mathrm{SSH}$ decrease in the subtropical areas $\left(20^{\circ} \mathrm{S}-40^{\circ} \mathrm{S}\right.$ and $\left.20^{\circ} \mathrm{N}-40^{\circ} \mathrm{N}\right)$ of the Pacific Ocean, while in the Indian Ocean it is well balanced by the thermal contribution (Fig. 8d). The latter is on the contrary the dominant contributor in the ACC and, less importantly, in the Atlantic Ocean.

To summarize, in the Tropics the major effect for which the sea level lowers is given by the freshwater mass flux decrease, while in the subtropical areas by the salinity changes due to circulation-induced effects. Finally, the SSH rise in the ACC is then given by the induced thermal increase.

\section{OSD}

$9,611-648,2012$

\section{A satellite-based correction of precipitation fluxes}

A. Storto et al.

\section{Title Page}

\section{Full Screen / Esc}

Printer-friendly Version

Interactive Discussion

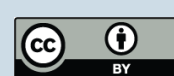




\subsection{Impact on ocean circulation and volume and freshwater transports}

Given the variations of density fields, for instance in areas of deep water formation as the ACC, it seems reasonable to investigate the variations of the ocean circulation, induced by the precipitation correction. This has been firstly evaluated by using 5 the Ocean Surface Current Analysis Real-time data (OSCAR, Bonjean and Lagerloef, 2002), which merges observations from altimeters and scatterometers to compute monthly means of $0-15 \mathrm{~m}$ currents. The results (Fig. 9) show that, on the global scale, the precipitation correction induces a weakening of the near-surface current system, which leads to RMSE decrease of about $0.5 \mathrm{~cm} \mathrm{~s}^{-1}$, corresponding to a $4 \%$ error decrease. In the Antarctic Circumpolar Current (ACC) region, the impact is particularly significant, as it reduces the current speed (faster than those of OSCAR of about $1 \mathrm{~cm} \mathrm{~s}^{-1}$ ) and decreases the RMSE of about $1.5 \mathrm{~cm} \mathrm{~s}^{-1}$, corresponding to a $9 \%$ error reduction.

In order to better appreciate the changes in the Global Ocean circulation produced 15 speed yielded by the precipitation correction for four different vertical regions, namely the surface $(0-100 \mathrm{~m})$, the intermediate $(100-1500 \mathrm{~m})$, the deep $(1500-4000 \mathrm{~m})$ and the bottom waters $(4000 \mathrm{~m}$ - bottom). The two panels of Fig. 10 show the mean current direction (when the correction is applied) and the differences in the current speed for surface and bottom waters. It can be seen, in general, that the correction induces a weakening in the Equatorial near-surface current systems, which is particularly large in correspondence of the Caribbean Current in the Atlantic Ocean, the Pacific Equatorial Counter Current and the East Australian Current and, in the Indian Ocean, the South Equatorial and the Mozambique currents. The Antarctic Circumpolar Current tion occurs. A slight decrease of surface current speed is also visible in the Bering Strait. In practice, it turned out that the subtropical gyres (especially the North Atlantic and North Pacific gyres) are importantly affected by the precipitation correction and all

\section{OSD}

$9,611-648,2012$

\section{A satellite-based correction of precipitation fluxes}

A. Storto et al.

\section{Title Page}

\section{Full Screen / Esc}

Printer-friendly Version

Interactive Discussion 
show a current speed decrease. The differences in current speed for intermediate waters generally decrease (not shown), although they remains significant in the Western boundary currents and in the Gulf Stream and Labrador Sea current systems. For deep and bottom ocean currents, we found a weakening in correspondence of the ACC and 5 the deep western boundary currents in both the Pacific and Atlantic Oceans, suggesting that the changes in the freshwater fluxes might have implications also on the global thermohaline circulation.

Consequently, we have compared the meridional freshwater transport (MFT) with estimates from both atmospheric reanalyses (Large and Yeager, 2009) and hydrographic 10 observations (Wijffels, 2001). The comparison is shown in Fig. 11 for the Global and the three main Oceans. At the global scale, the correction leads to a MFT decrease in the Northern Hemisphere and an increase in the Southern Hemisphere. Both these changes better agree with both the observational and atmospheric estimates. A better agreement with these independent estimates is also found in the North Pacific and in 15 the Indian Ocean, while the impact of the correction in the North Atlantic is slightly negative with respect to the estimates of Large and Yeager (2009).

In Fig. 12, we show the cross-sections of the mean meridional velocity of the experiment with the correction, the salinity anomaly and MSSH for the two experiments and the mean difference of the meridional velocity and meridional freshwater trans20 port between the two experiments, for a North Pacific section at $25^{\circ} \mathrm{N}$, with the aim of explaining the mechanism that leads to a meridional freshwater decrease in the Pacific subtropical gyres. The western boundary currents, in correspondence of the Kuroshio Current, directed northward at $25^{\circ} \mathrm{N}$, are by far the strongest meridional currents, reaching a maximum mean value of $67 \mathrm{~cm} \mathrm{~s}^{-1}$ at $122.5^{\circ} \mathrm{E}$ at the sea-surface.

25 The application of the correction leads to a weakening of the subtropical circulation, and the meridional velocity decrease at $25^{\circ} \mathrm{N}$ is then compensated by a weaker meridional southward California current and a reduced volume transport in the Bering Strait (see Table 2 discussed later on). The mechanism upon which the circulation weakens is explained by the fact that in the Western Equatorial Pacific the precipitation diminution

\section{OSD}

$9,611-648,2012$

\section{A satellite-based correction of precipitation fluxes}

A. Storto et al.

Title Page

Abstract Introduction

Conclusions

Tables

References

Figures

14

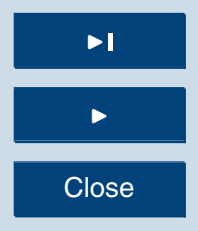

Back

Close

Printer-friendly Version

Interactive Discussion 
yields a zonal MSSH gradient decrease and a density increase. As a consequence, the Kuroshio Current decreases and likewise the volume transport in the Bering Strait and in correspondence of the California Current. In terms of meridional freshwater transport, the decrease of transport in the North Atlantic and Pacific Oceans is then 5 explained by the change in the transport mostly in the western boundary current. In the North Pacific, the combined effect of the western salinification and northward current decrease leads to a freshwater transport, with maximum values between 122 and $123^{\circ} \mathrm{E}$ at around $400 \mathrm{~m}$ of depth. Since the effects of the precipitation correction are rather similar in the other Oceans, with a tropical salinification spread northward and 10 southward by weakened western boundary currents, similar results apply also to the Atlantic and Indian Oceans.

As final summarizing diagnostics, we evaluated for both the experiments the volume and freshwater transports across some sections of particular interest. The results are reported in Table 2, in terms of mean value for the 1989-2009 period and standard 15 deviations of the monthly means. The volume and freshwater transports of the Antarctic Circumpolar Current south of Australia decrease from 192.23 to $169.98(-12 \%)$ and 2.25 to $2.15 \mathrm{~Sv}(-4 \%)$, respectively, and better agree with the estimates of Rintoul and Sokolov (2001) (147 $\pm 10 \mathrm{~Sv})$, suggesting that the ACC is generally overestimated and the precipitation correction has a mitigating effect. The Bering Strait volume transport is less affected by the precipitation correction (1.76 to $1.67 \mathrm{~Sv}$, corresponding to a $-5 \%$ reduction), which however mitigates the transport overestimation with regards to the observed value of $0.8 \mathrm{~Sv}$ found by Roach et al. (1995). The change seems to be solely caused by the weakening of the surface current system, since subsurface currents between the two experiments do not exhibit significant variations. No significant impact was found on the freshwater transport. For the Fraim Strait, the volume transport increases from $1.94 \pm 1.06$ to $2.53 \pm 0.97 \mathrm{~Sv}(+30 \%)$ and gets closer to the value of $4 \pm 2$ Sv given by Schauer et al. (2004). Across the Drake Passage the volume transport decreases from $177.46 \pm 13.70 \mathrm{~Sv}$ to $159.70 \pm 23.27 \mathrm{~Sv}(-10 \%)$, thus being more similar to the $134.00 \pm 11.20 \mathrm{~Sv}$ estimate of Cunningham et al. (2003), consistently with

\section{OSD}

$9,611-648,2012$

\section{A satellite-based correction of precipitation fluxes}

A. Storto et al.

Title Page

Abstract Introduction

Conclusions

Tables References Figures
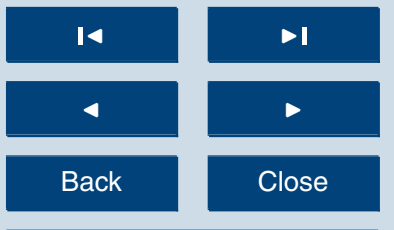

Full Screen / Esc

Printer-friendly Version

Interactive Discussion 
the results found for the ACC east of Australia. Also the transports through the Indonesian Throughflow are better represented with the precipitation correction: the mean volume transport decreases from 20.97 to $18.95 \mathrm{~Sv}(-10 \%)$ and gets closer to the value of $15 \mathrm{~Sv}$ found by Gordon et al. (2009). On the other hand, as a consequence of 5 the large salinity increase in the Indonesian region due to the precipitation correction, the freshwater transport decreases from $0.43 \pm 0.21$ to $0.28 \pm 0.15 \mathrm{~Sv}(-35 \%)$, and better agrees with the estimate of $0.23 \pm 0.05 \mathrm{~Sv}$ of Talley (2008), and the observed value of $0.14 \pm 0.04 \mathrm{~Sv}$ of Fang et al. (2010).

\section{Summary}

10 We have implemented an empirical correction procedure applied to the ERA-Interim reanalysis precipitation and based on a monthly climatological corrective coefficient deduced from the comparison between large-scale precipitation from ERA-Interim and the microwave satellite product PMWC. We have investigated the main mechanisms that the correction leads to, and validated the results against independent observation 15 datasets.

The correction has a largely positive effect not only in reducing the fresh bias of the near-surface salinity in the Tropics (up to 1 psu of bias reduction) and the salty bias in mid-latitudes, but also in improving the sea level variability representation ( $8 \%$ of globally-averaged SLA RMSE decrease), especially in the South Pacific Ocean, and the near-surface circulation, particularly in correspondence of the ACC (the latter exhibiting a $9 \% 0-15 \mathrm{~m}$ current speed RMSE reduction). We were able to investigate in details the effects of the correction on the sea level inter-annual variability, and concluded that the barotropic lowering of sea level dominates in the Equatorial regions, while the baroclinic response in the subtropical regions causes also there an SSH lowering.

The correction also yields a $16 \%$ reduction of the global net freshwater flux imbalance; although the imbalance after the correction does not allow to be neglected if one
OSD

9, 611-648, 2012

\section{A satellite-based correction of precipitation fluxes}

A. Storto et al.

\section{Title Page}

\section{Full Screen / Esc}

Printer-friendly Version

Interactive Discussion 
wants to have realistic sea level trend, this value seems however important in reducing the remote effect of the superimposed closure of the globally-averaged freshwater flux.

The correction has also been shown to cause an improved representation of the volume and freshwater transports. One of the most appreciable results is the weakening 5 of the ACC volume transport of about 20 Sv (corresponding to a decrease between -10 and $-12 \%$ ), which mitigates the previous overestimation with the uncorrected rain rates, and which is mostly due to the current speed reduction found in the Southern Oceans.

The use of more sophisticated techniques for the calibration of atmospheric reanal10 yses precipitation, for instance consisting in quantile-based bias-correction, was not considered in this study but will be explored in the future, since the main motivation of the present work is the study of the potential impact of satellite products for correcting atmospheric model precipitation products. As an additional perspective, we also plan to study the benefits of correcting the atmospheric reanalysis precipitation by using 15 different observational dataset (e.g. the Global Precipitation Climatology Project, Huffman et al., 2009) or synthetic dataset that merge observations and atmospheric model data (e.g. the Multi-Source Analysis of Precipitation, MSAP, Sapiano et al., 2008), with the general idea of further reducing the time-mean value of the globally-averaged EMP imbalance to values comparable to the estimates derived from gravimetric data.

20 Acknowledgements. This work has been conducted in the framework of the Work Package 4 (Global Ocean Monitoring and Forecasting) of MyOcean, a European Commission funded project within the Global Monitoring for Environment and Security (GMES) Program. PMWC Precipitation data are produced by Remote Sensing Systems and sponsored by the NASA Energy and Water Study Program. Data are available at www.remss.com. The authors want 25 to thank the TAO Project Office of NOAA/PMEL for providing the TAO/TRITON/RAMA/PIRATA dataset and the OSCAR Project Office for the ocean surface current dataset. The altimeter products were produced by Ssalto/Duacs and distributed by Aviso, with support from Cnes (http://www.aviso.oceanobs.com/duacs/). We thank Stephen Yeager (UCAR) for having provided the atmospheric reanalysis-derived dataset of meridional freshwater transport. We thank 30 Paolo Oddo and Antonio Navarra for fruitful discussions.

\section{OSD}

$9,611-648,2012$

\section{A satellite-based correction of precipitation fluxes}

A. Storto et al.

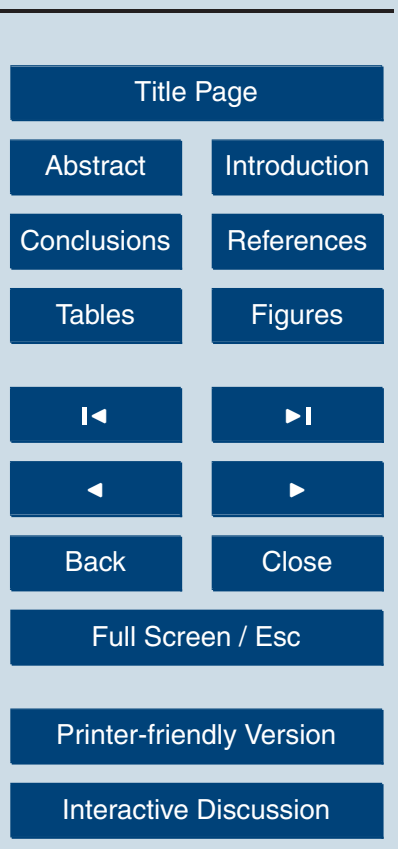

630 


\section{References}

Antonov, J. I., Seidov, D., Boyer, T. P., Locarnini, R. A., Mishonov, A. V., Garcia, H. E., Baranova, O. K., Zweng, M. M., and Johnson, D. R.: World Ocean Atlas 2009, Vol. 2: Salinity, in: NOAA Atlas NESDIS 69, edited by: US Government Printing Office, Washington DC, 184 pp., 2010.

Arpe, K., Klepp, C., and Rhodin, A.: Differences in the hydrological cycles from different reanalyses - which one shall we believe?, Proc. Conf. 2nd Intl. Conference on Reanalyses, Reading, UK, 23-27 August 1999, 2000.

Beron-Vera, F. J., Ochoa, J., and Ripa, P.: A note on boundary conditions for salt and freshwater balances, Ocean Model., 1, 111-118, 1999.

Bonjean, F. and Lagerloef, G. S. E.: Diagnostic model and analysis of the surface currents in the Tropical Pacific Ocean, J. Phys. Oceanogr., 32, 2938-2954, 2002.

Bourdalle-Badie, R. and Treguier, A. M.: A Climatology of Runoff for the Global Ocean-Ice Model ORCA025, Mercator-Ocean report, MOO-RP-425-365-MER, 2006.

15 Cazenave, A., Dominh, K., Guinehut, S., Berthier, E., Llovel, W., Ramillien, G., Ablain, M., and Larnicol, G.: Sea level budget over 2003-2008: a revaluation from GRACE space gravimetry, satellite altimetry and Argo, Global Planet. Change, 65, 83-88, 2009.

Cummingham, S. A., Alderson, S. G., King, B. A., and Brandon, M. A.: Transport and variability of the Antarctic Circumpolar Current in Drake Passage, J. Geophys. Res., 108, C58084, 20 doi:10.1029/2001JC001147, 2003.

Dai, A. and Trenberth, K. E.: Estimates of freshwater discharge from continents: Latitudinal and seasonal variations, J. Hydrometeorol., 3, 660-687, 2002.

Dhomps, A. -L., Guinehut, S., Le Traon, P.-Y., and Larnicol, G.: A global comparison of Argo and satellite altimetry observations, Ocean Sci., 7, 175-183, doi:10.5194/os-7-175-2011, 2011.

Dombrowsky, E., Bertino, L., Brassington, G., Chassignet, E. P., Davidson, F., Hurlburt, H. E., Kamachi, M., Lee, T., Martin, M. J., Mei, S., and Tonani, M.: GODAE systems in operation, Oceanography, 22, 80-95, 2009.

Fang, G., Susanto, R. D., Wirasantosa, S., Qiao, F., Supangat, A., Fan, B., Wei, Z., Sulistiyo, B., and Li, S.: Volume, heat and freshwater transports from the South China Sea to the Indonesian seas in the boral winter of 2007-2008, J. Geophys. Res., 115, C12020, doi:10.1029/2010JC006225, 2010.

\section{OSD}

$9,611-648,2012$

\section{A satellite-based correction of precipitation fluxes}

A. Storto et al.

\section{Title Page}

Abstract

\section{Full Screen / Esc}

Printer-friendly Version

Interactive Discussion 
Feudale, L. and Tompkins, A. M.: A simple bias correction technique for modeled monsoon precipitation applied to West Africa, Geophys. Res. Lett., 38, L03803, doi:10.1029/2010GL045909, 2011.

Fichefet, T. and Morales Maqueda, M. A.: Sensitivity of a global sea ice model to the treatment of ice thermodynamics and dynamics, J. Geophys. Res., 102, 12609-12646, 1997.

Garric, G., Verbrugge, N., and Bricaud, C.: Large scale ERAinterim radiative and precipitation surface fluxes assessment, correction and application on 1/4 global ocean 1989-2009 hindcasts, EGU General Assembly 2011, Vienna, Austria, 4-8 April 2011, 2011.

Gill, A.: Atmosphere-Ocean Dynamics, Elsevier, New York, 662 pp., 1982.

10 Gordon, A. L., Sprintall, J., Van Haken, H. M., Susanto, D., Wijffels, S., Molcard, R., Ffield, A., Pranowo, W., and Wirasantosa, S.: The Indonesian throughflow during 2004-2006 as observed by the INSTANT Program, Dynam. Atmos. Oceans, 50, 115-128, 2010.

Hilburn, K. and Wentz, F.: Intercalibrated passive microwave rain products from the Unified Microwave Ocean Retrieval Algorithm (UMORA), J. Appl. Metorol. Clim., 47, 778-794, 2008.

Hilburn, K.: The passive microwave water cycle product, Remote Sensing Systems (REMSS) Technical Report 072409, Santa Rosa (CA), 30 pp., 2009.

Huang, R. X.: Real freshwater flux as a natural boundary condition for the salinity balance and thermohaline circulation forced by evaporation and precipitation, J. Phys. Oceanogr., 23, 2428-2446, 1993.

20 Huang, R. X. and Schmitt, R. W.: The Goldsbrough-Stommel circulation of the World oceans, J. Phys. Oceanogr., 23, 1277-1284, 1993.

Huffman, G. J., Adler, R. F., Bolvin, T. D., and Gu, G.: Improving the global precipitation record: GPCP Version 2.1, Geophys. Res. Lett., 36, L17808, doi:10.1029/2009GL040000, 2009.

Janowiak, J. E., Gruber, A., Kondragunta, C. R., Livezey, R. E., and Huffman, G. J.: A comparison of the NCEP/NCAR reanalysis precipitation and the GPCP raingauge-satellite combined data set with observational error considerations, J. Climate, 11, 2960-2979, 1998.

Janowiak, J. E., Bauer, P., Wang, W., Arkin, P., and Gottschalck, J.: An evaluation of precipitation forecasts from operational models and reanalyses including precipitation variations associated with MJO activity, Mon. Weather Rev., 138, 4542-4560, 2010.

30 Lagerloef, G., Schmitt, R., Schanze, J., and Kao, H.-Y.: The ocean and the global water cycle, Oceanography, 23, 82-93, 2010.

Large, W. G. and Yeager, S. G.: The global climatology of an inter-annually varying air-sea flux data set, Clim. Dyn., 33, 341-364, 2009.
OSD

$9,611-648,2012$

\section{A satellite-based correction of precipitation fluxes}

A. Storto et al.

\section{Title Page}

Abstract

Conclusions

References

Tables

Figures

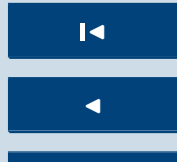

$\rightarrow 1$

Back

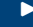

Close

Full Screen / Esc

Printer-friendly Version

Interactive Discussion

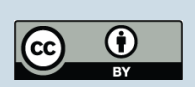


Levitus, S., Boyer, T. P., Conkright, M. E., O’ Brien, T., Antonov, J., Stephens, C., Stathoplos, L., Johnson, D., and Gelfeld, R.: NOAA Atlas NESDIS 18, World Ocean Database 1998, US Gov. Printing Office, Washington, DC 1998.

Lowe, J. A. and Gregory, J. M.: Understanding projections of sea level rise in a Hadley Center coupled climate model, J. Geophys. Res., 111, C11014, doi:10.1029/2005JC003421, 2006.

Madec, G.: NEMO ocean engine, Note du Pole de modelisation, Institut Pierre-Simon Laplace (IPSL), France, No. 27, ISSN 1288-619, 2008.

Mariotti, A., Struglia, M. V., Zeng, N., and Lau, K.-M.: The hydrological cycle in the Mediterranean region and implications for the water budget of the Mediterranean Sea, J. Climate,

$10 \quad$ 15, 1674-1690, 2002.

Marsh, R., Desbruyères, D., Bamber, J. L., de Cuevas, B. A., Coward, A. C., and Aksenov, Y.: Short-term impacts of enhanced Greenland freshwater fluxes in an eddy-permitting ocean model, Ocean Sci., 6, 749-760, doi:10.5194/os-6-749-2010, 2010.

Masina, S., Di Pietro, P., Storto, A., and Navarra, A.: Global ocean re-analyses for climate applications, Dynam. Atmos. Oceans, 52, 341-366, 2011.

Pettenuzzo, D., Large, W. G., and Pinardi, N.: On the corrections of ERA-40 surface flux products consistent with the Mediterranean heat and water budgets and the connection between basin surface total heat flux and NAO, J. Geophys. Res., 115, C06022, doi:10.1029/2009JC005631, 2010.

20 Pinardi, N., and Rosati, A., and Pacanowski, R. C.: The sea surface pressure formulation of rigid lid models. Implications for altimetric data assimilation studies, J. Marine Syst., 6, 109119, 1995.

Ponte, R. M.: Oceanic response to surface loading effects neglected in volume-conserving models, J. Phys. Oceanogr., 36, 426-434, 2006.

Rintoul, S. R. and Sokolov, S.: Baroclinic transport variability of the Antarctic Circumpolar Current south of Australia, J. Geophys. Res., 106, 2815-2832, 2001.

Risien, C. M. and Chelton, D. B.: A Global climatology of surface wind and wind stress fields from eight years of QuikSCAT scatterometer data, J. Phys. Oceanogr., 38, 2379-2413, 2008.

Roach, A. T., Aagaard, K., Pease, C. H., Salo, S. A., Weingartner, T., Pavlov, V., and Kulakov, M.:

30 Direct measurements of transport and water properties through the Bering Strait, J. Geophys. Res., 100, 18443-18457, 1995.

Sapiano, M. R. P., Smith, T. M., and Arkin, P. A.: A new merged analysis of precipitation utilizing satellite and reanalysis data, J. Geophys. Res., 113, D22103, doi:10.1029/2008JD010310,

OSD

$9,611-648,2012$

\section{A satellite-based correction of precipitation fluxes}

A. Storto et al.

\section{Title Page}

Abstract

\section{Full Screen / Esc}

Printer-friendly Version

Interactive Discussion 
2008.

Schauer, U., Fahrbach, E., Osterhus, S., and Rohardt. G.: Arctic warming through the Fraim Strait: oceanic heat transport from 3 years of measurements, J. Geophys. Res., 109, C06026, doi:10.1029/2003JC001823, 2004.

5 Simmons, A., Uppala, S., Dee, D., and Kobayashi, S.: ERA-Interim: New ECMWF reanalysis products from 1989 onwards, ECMWF Newsletter 110, ECMWF, Reading, UK, 2007.

Stammer, D., Ueyoshi, K., Kohl, A., Large, W. G., Josey, S. A., and Wunsch, C.: Estimating air-sea fluxes of heat, freshwater and momentum through global ocean data assimilation, J. Geophys. Res., 109, C05023, doi:10.1029/2003JC002082, 2004.

Stendel, M. and Arpe, K.: Evaluation of the hydrological cycle in reanalyses and observations, Report 228, Max Planck Institut für Meteorologie, Hamburg, Germany, 52 pp., 1997.

Storto, A., Dobricic, S., Masina, S., and Di Pietro, P.: Assimilating along-track altimetric observations through a local hydrostatic adjustment scheme in a Global Ocean variational assimilation system, Mon. Weather Rev., 139, 738-754, 2011.

Talley, L. D.: Freshwater transport estimates and the global overturning circulation: shallow, deep and throughflow components, Prog. Oceanogr., 78, 257-303, 2008.

Yang, D., Kane, D., and Zhang, Z.: Bias corrections of long-term (1973-2004) daily precipitation data over the northern regions, Geophys. Res. Lett., 32, L19501, doi:10.1029/2005GL024057, 2005.

20 Wijffels, S.: Ocean transport of fresh water, in: Ocean Circulation and Climate, edited by: Siedler, G., Church, J. A., and Gould, J., Academic Press, San Diego, 475-488, 2001.
OSD

$9,611-648,2012$

\section{A satellite-based correction of precipitation fluxes}

A. Storto et al.

\section{Title Page}

Abstract

Introduction

Conclusions

References

Tables

Figures

14

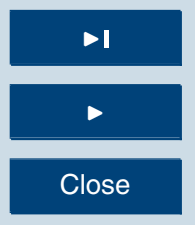

Back

Close

Full Screen / Esc

Printer-friendly Version

Interactive Discussion 


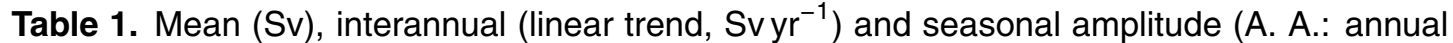
amplitude; S.-A. A.: semi-annual amplitude, both in Sv) for the precipitation, the runoff, the evaporation and the net upward freshwater fluxes (EMP).

\begin{tabular}{|c|c|c|c|}
\hline Experiment & & ERA-Interim & Era-Interim+PMWC \\
\hline \multirow[t]{4}{*}{ Precipitation } & Mean & 13.530 & 13.487 \\
\hline & Trend & -0.028 & -0.017 \\
\hline & A. A. & 0.032 & 0.484 \\
\hline & S.-A. A. & 0.197 & 0.230 \\
\hline \multirow[t]{4}{*}{ Evaporation } & Mean & 14.584 & 14.581 \\
\hline & Trend & 0.014 & 0.012 \\
\hline & A. A. & 0.140 & 0.138 \\
\hline & S.-A. A. & 0.273 & 0.280 \\
\hline \multirow[t]{4}{*}{ Runoff } & Mean & & 1.309 \\
\hline & Trend & & - \\
\hline & A. A. & & 0.298 \\
\hline & S.-A. A. & & 0.084 \\
\hline \multirow[t]{4}{*}{ EMP } & Mean & -0.255 & -0.215 \\
\hline & Trend & 0.042 & 0.031 \\
\hline & A. A. & 0.426 & 0.543 \\
\hline & S.-A. A. & 0.234 & 0.281 \\
\hline
\end{tabular}

\section{OSD}

$9,611-648,2012$

\section{A satellite-based correction of precipitation fluxes}

A. Storto et al.

\section{Title Page}

\section{Abstract}

Introduction

Conclusions

References

Tables

Figures
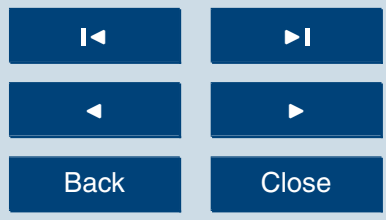

Back

Close

Full Screen / Esc

Printer-friendly Version

Interactive Discussion 
Table 2. Volume and freshwater transports (mean and standard deviation, Sv) through different ocean sections for the two experiments without and with the precipitation correction. Directions are as follows: 1 eastward; 2 northward; 3 westward; 4 southward.

\begin{tabular}{|c|c|c|c|c|c|c|c|c|c|}
\hline \multirow[t]{3}{*}{ Region } & \multirow[t]{3}{*}{ Dir } & \multicolumn{4}{|c|}{ No correction } & \multicolumn{4}{|c|}{ Precipitation Correction } \\
\hline & & \multicolumn{2}{|c|}{ Volume transp. } & \multicolumn{2}{|c|}{ Freshwater transp. } & \multicolumn{2}{|c|}{ Volume transp. } & \multicolumn{2}{|c|}{ Freshwater transp. } \\
\hline & & Mean & St. dev. & Mean & St. dev. & Mean & St. dev. & Mean & St. dev. \\
\hline Australian ACC & 1 & 192.23 & 15.73 & 2.25 & 0.14 & 169.98 & 41.87 & 2.15 & 0.54 \\
\hline Bering Strait & 2 & 1.76 & 0.50 & 0.11 & 0.04 & 1.67 & 0.50 & 0.12 & 0.04 \\
\hline Drake Passage & 1 & 177.46 & 13.70 & 2.30 & 0.14 & 159.70 & 23.27 & 2.22 & 0.34 \\
\hline Fram Strait & 4 & 1.94 & 1.06 & 0.03 & 0.02 & 2.53 & 0.97 & 0.04 & 0.02 \\
\hline ITF & 3 & 20.97 & 4.30 & 0.43 & 0.21 & 18.95 & 5.77 & 0.28 & 0.15 \\
\hline
\end{tabular}

\section{A satellite-based correction of precipitation fluxes}

A. Storto et al.

Title Page

\section{Abstract}

Introduction

Conclusions

References

Tables

Figures

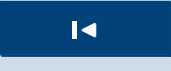

4

Back

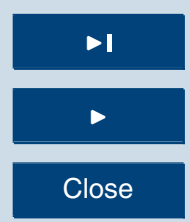

Full Screen / Esc

Printer-friendly Version

Interactive Discussion 


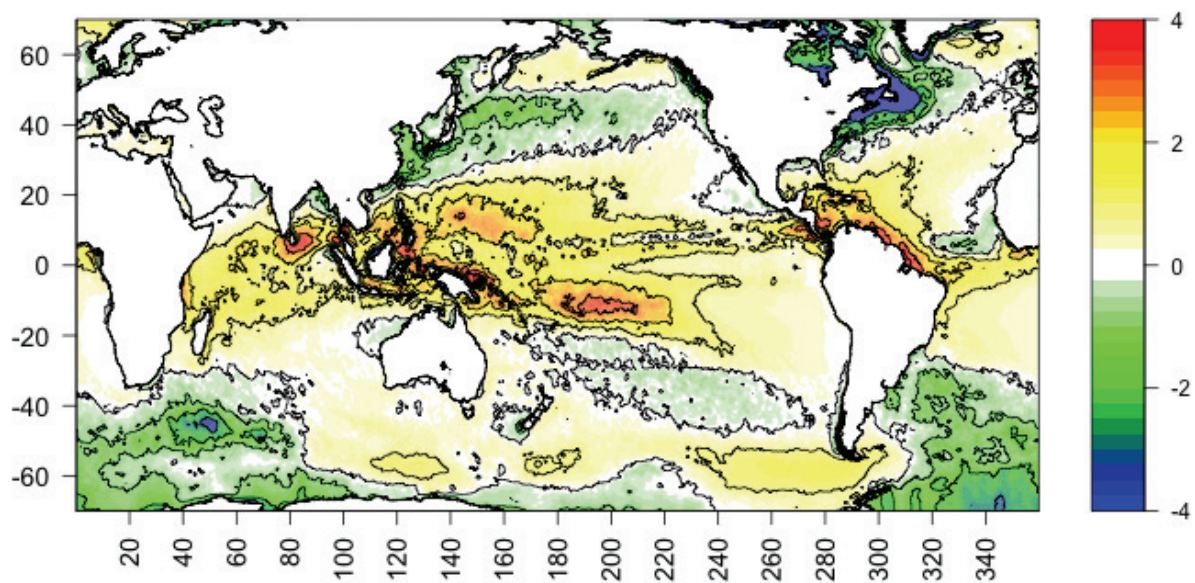

Fig. 1. Bias between ERA-Interim and PMWC precipitation for the period 1989-2008 in $\mathrm{mm} \mathrm{d}^{-1}$. The contour interval is $1 \mathrm{~mm} \mathrm{~d}^{-1}$.
OSD

$9,611-648,2012$

\section{A satellite-based correction of precipitation fluxes}

A. Storto et al.

\section{Title Page}

Abstract

Introduction

Conclusions

References

Tables

Figures

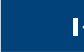

Back

Full Screen / Esc

Printer-friendly Version

Interactive Discussion

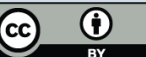




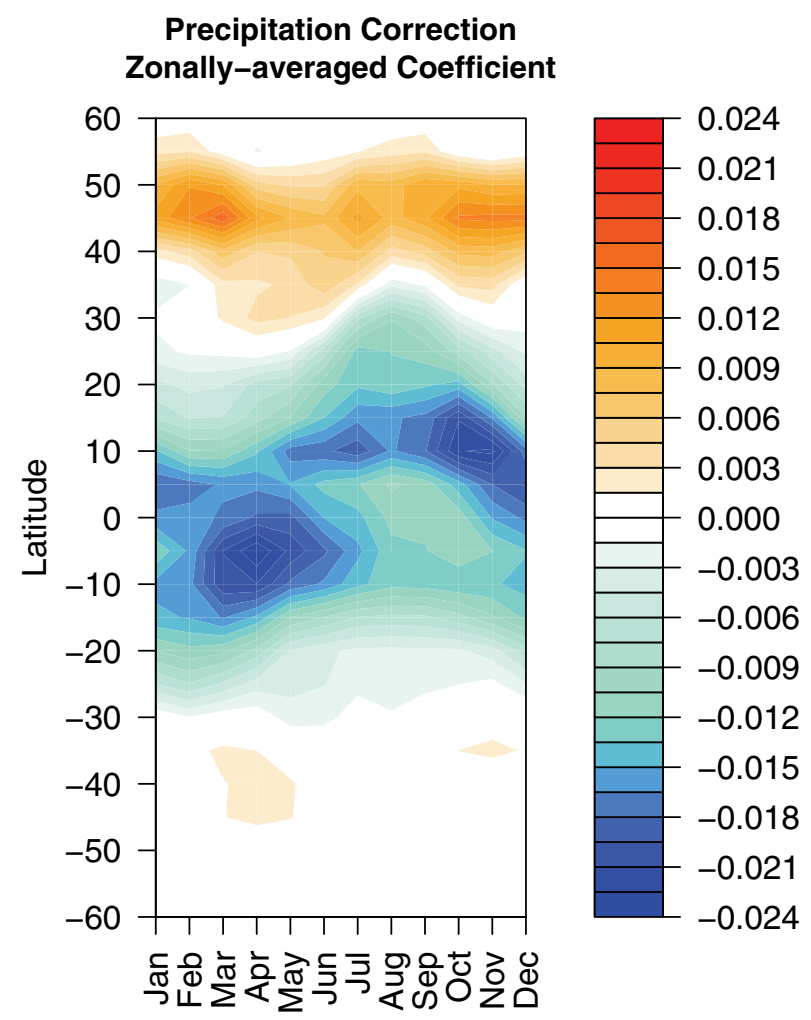

Fig. 2. Contours of the zonally averaged climatological precipitation corrective coefficient as a function of month.

\section{OSD}

$9,611-648,2012$

\section{A satellite-based correction of precipitation fluxes}

A. Storto et al.

\section{Title Page}

\section{Abstract}

Introduction

Conclusions

References

Tables

Figures

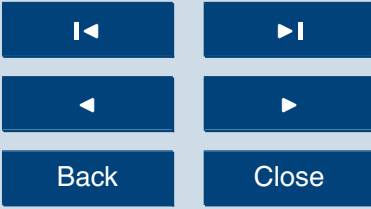

Full Screen / Esc

Printer-friendly Version

Interactive Discussion 


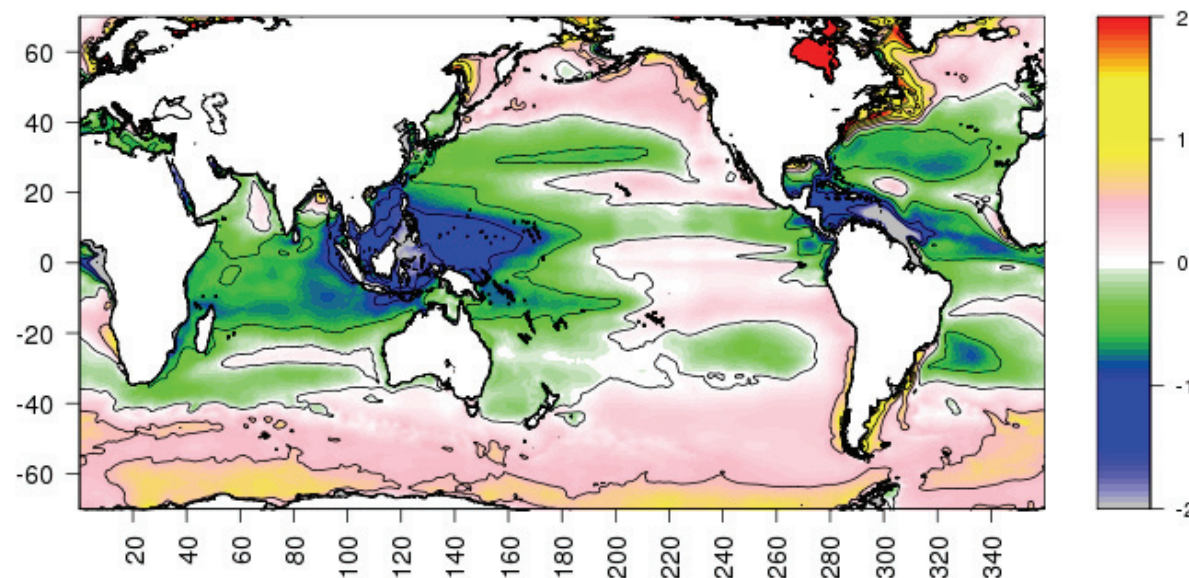

OSD

9, 611-648, 2012

\section{A satellite-based correction of precipitation fluxes}

A. Storto et al.

\section{Title Page}

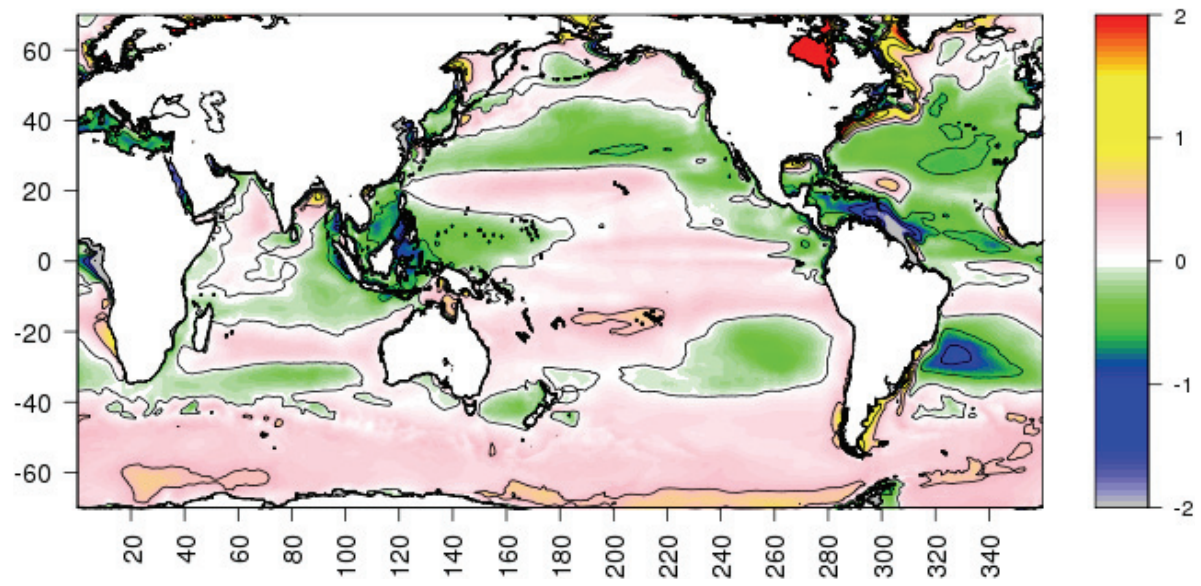

\section{Abstract}

Introduction

Conclusions

References

Tables

Figures
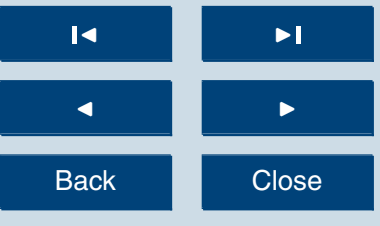

Back

Close

\section{Full Screen / Esc}

Printer-friendly Version

Fig. 3. Difference between ocean model sea-surface salinity (psu) and WOA2009 climatological salinity without (top) and with (bottom) the application of the correction to the precipitation fluxes. The contour interval is $0.5 \mathrm{psu}$. 

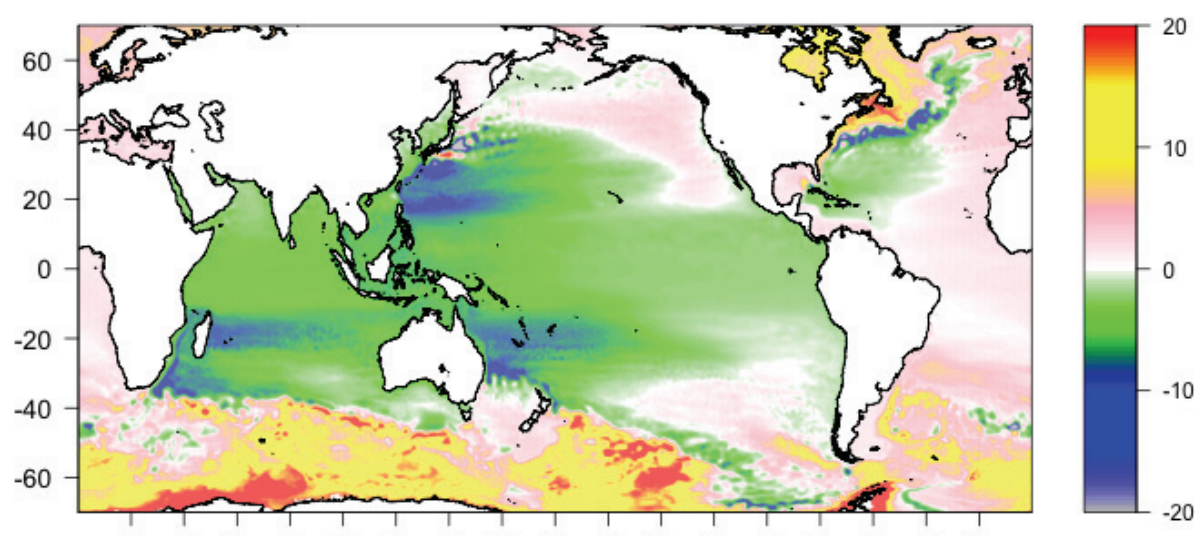

OSD

9, 611-648, 2012

\section{A satellite-based correction of precipitation fluxes}

A. Storto et al.

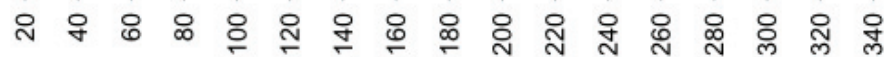

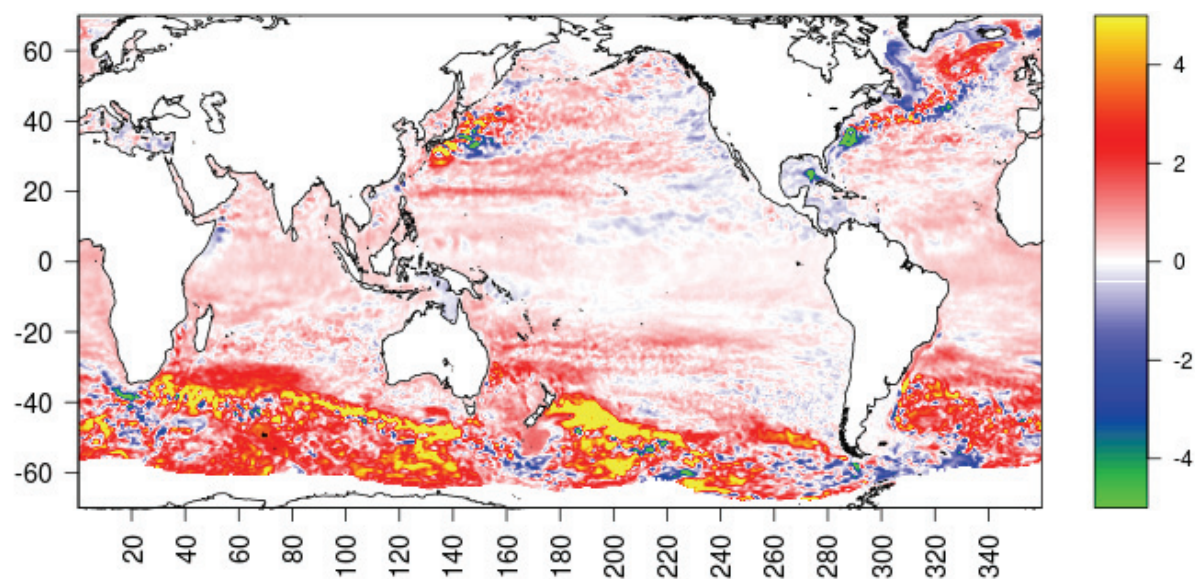

Title Page

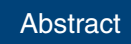

Introduction

Conclusions

References

Tables

Figures
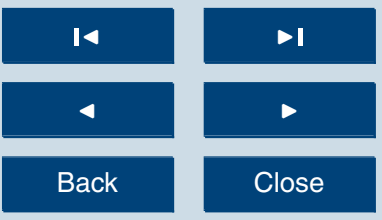

Back

Close

\section{Full Screen / Esc}

Printer-friendly Version

Fig. 4. Top: mean sea-surface height difference $(\mathrm{cm})$ between the experiment with and without the precipitation correction. Bottom: sea-surface height RMSE (against AVISO/SLA) decrease $(\mathrm{cm})$ due to the precipitation correction: positive (negative) values indicate a decrease (increase) of RMSE. 


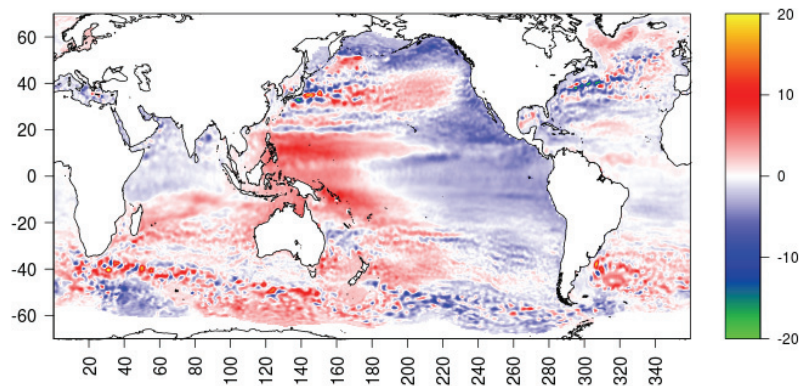

OSD

$9,611-648,2012$

\section{A satellite-based correction of precipitation fluxes}

A. Storto et al.

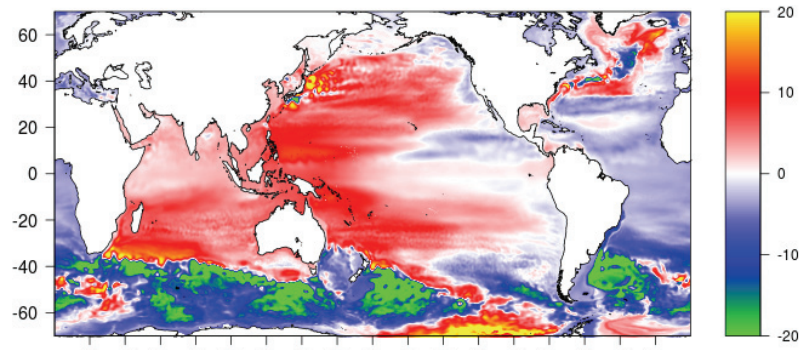

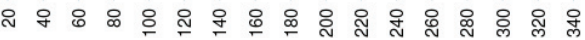

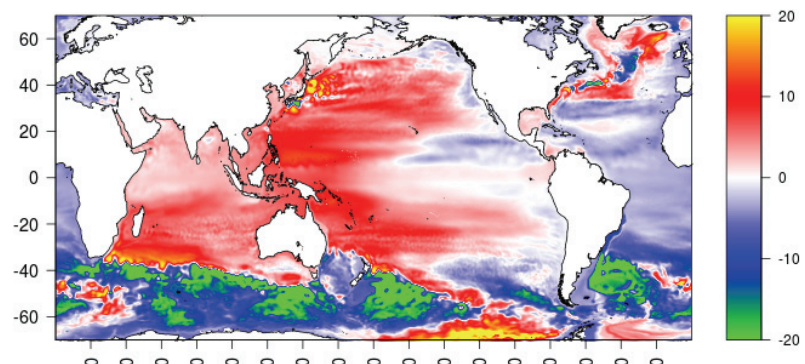

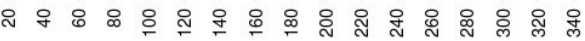

Fig. 5. Sea level linear trend $\left(\mathrm{mm} \mathrm{y}^{-1}\right)$ for the period 1993-2009. Top: from altimetric observations (monthly gridded merged products from CLS/AVISO); middle: without the precipitation correction; bottom: with the precipitation correction.

Title Page

Abstract

Introduction

Conclusions

References

Tables

Figures

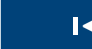

14

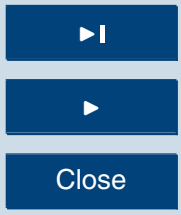

Back

Close

Full Screen / Esc

Printer-friendly Version

Interactive Discussion

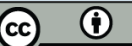



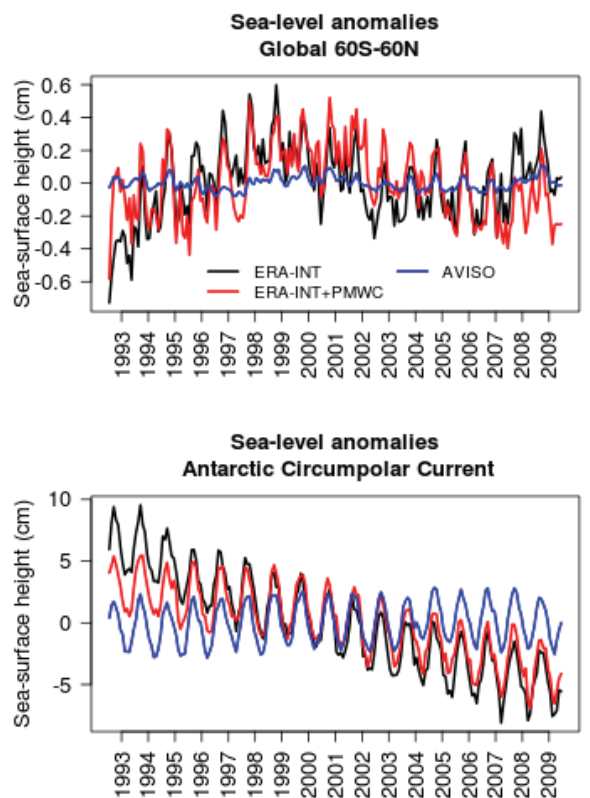

RMSE against AVISO sea-level anomalies Global $605-60 \mathrm{~N}$

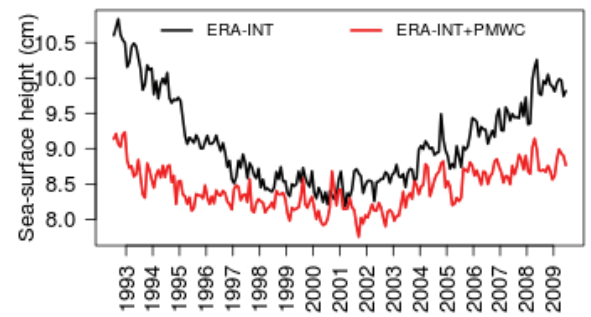

RMSE against AVISO sea-level anomalies Antarctic Circumpolar Current

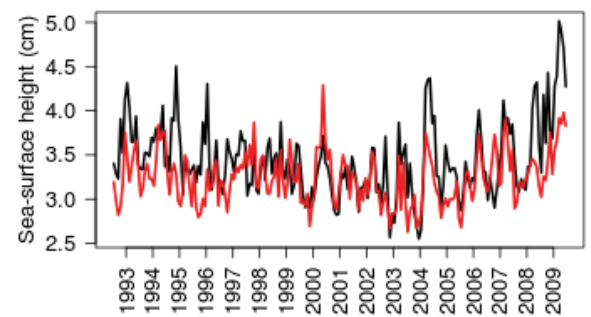

Fig. 6. Basin averaged sea level anomaly timeseries (left panels) and RMSE against the AVISO monthly gridded altimetric data (right panels) for both the Global Ocean $\left(60^{\circ} \mathrm{S}-60^{\circ} \mathrm{N}\right)$ and the ACC.

\section{A satellite-based correction of precipitation fluxes}

A. Storto et al.

\section{Title Page}

Abstract

Introduction

Conclusions

References

Tables

Figures
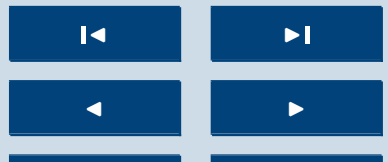

Back

Close

\section{Full Screen / Esc}

Printer-friendly Version

Interactive Discussion 


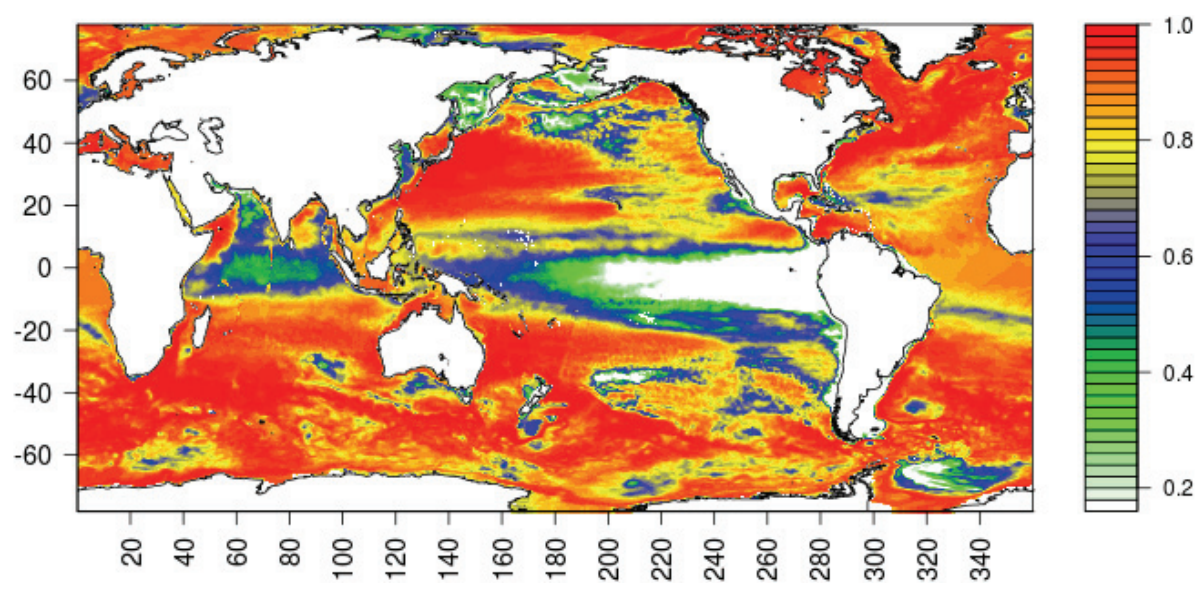

Fig. 7. Correlation between differences in sea-surface heights and dynamic heights that approximate the baroclinic component of sea level. Values are bounded between 0.16 and 1, where the former value is the minimum significant correlation at $99 \%$ of confidence level.

\section{OSD}

$9,611-648,2012$

\section{A satellite-based correction of precipitation fluxes}

A. Storto et al.

\section{Title Page}

\section{Abstract}

Introduction

Conclusions

References

Tables

Figures

14

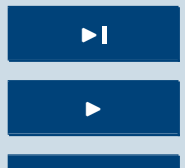

Back

Close

Full Screen / Esc

Printer-friendly Version

Interactive Discussion 


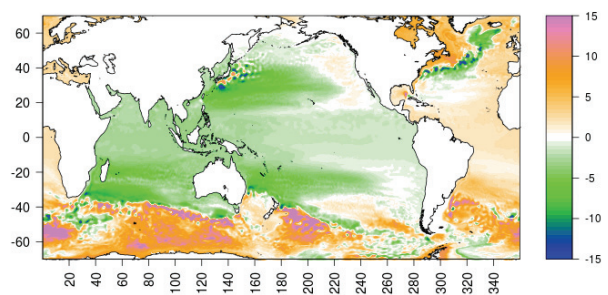

(a)

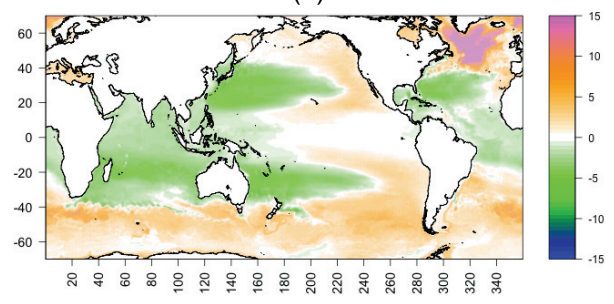

(c)

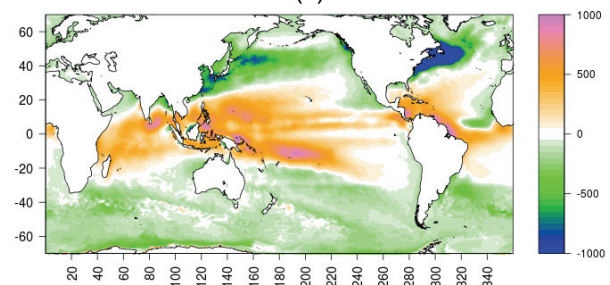

(f)

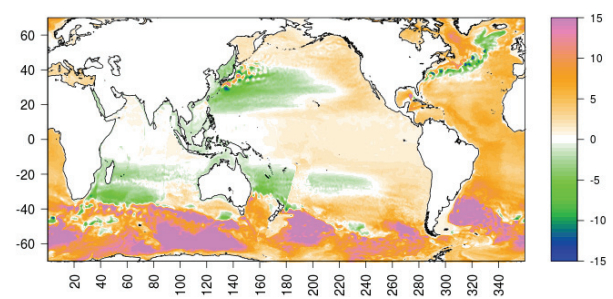

(b)

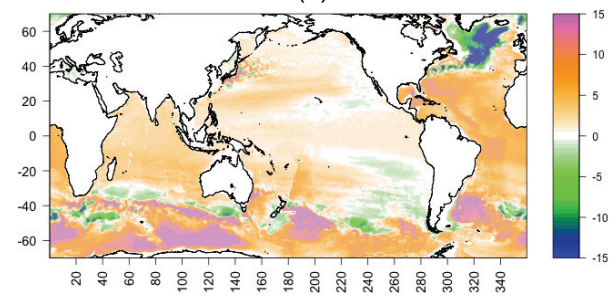

(d)

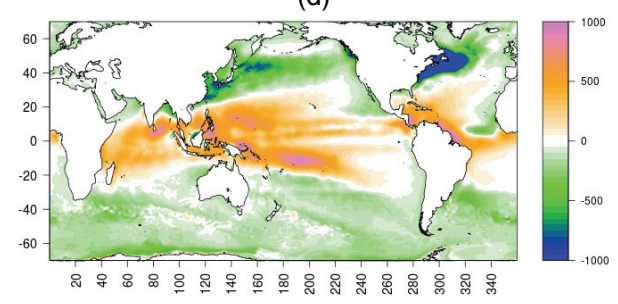

(f)

Fig. 8. Contributions to the interannual sea level trends in $\mathrm{mm} \mathrm{yr}^{-1}$ : total sea level (a); total baroclinic sea level (b); halosteric sea level (c); thermosteric sea level (d); sea level from EMP contribution (e) and from the vertical integral of the horizontal divergence (f).

OSD

$9,611-648,2012$

\section{A satellite-based correction of precipitation fluxes}

A. Storto et al.

\section{Title Page}

\section{Abstract}

Introduction

Conclusions

References

Tables

Figures
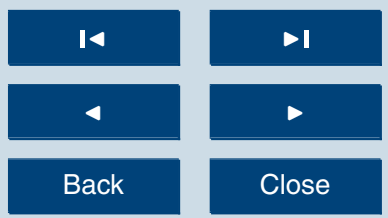

Full Screen / Esc

Printer-friendly Version

Interactive Discussion 
Bias against OSCAR current speed Global 60S-60N

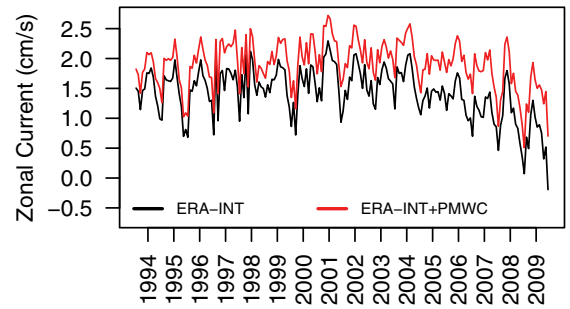

Bias against OSCAR current speed Antarctic Circumpolar Current

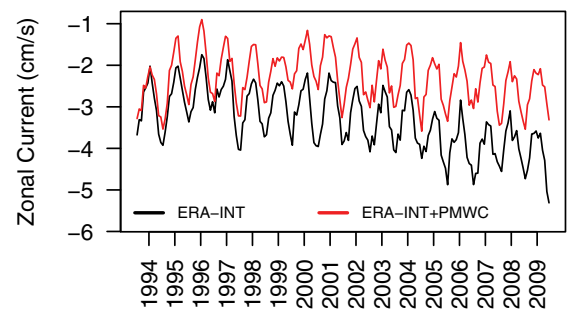

RMSE against OSCAR current speed Global 60S-60N

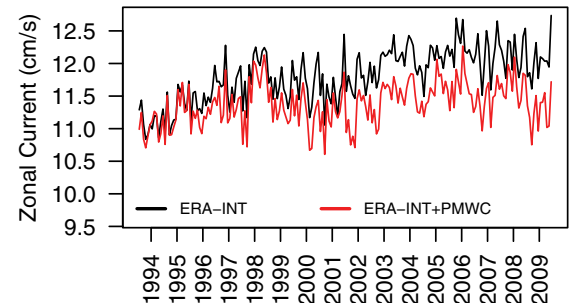

RMSE against OSCAR current speed Antarctic Circumpolar Current

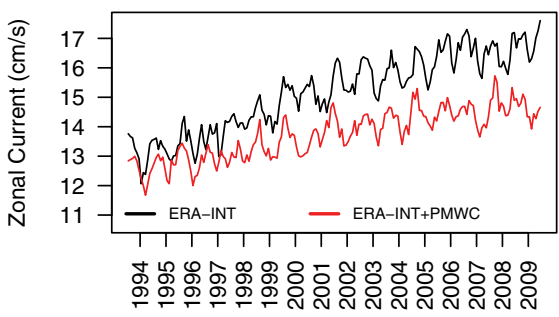

Fig. 9. Near-surface current speed bias and RMSE against the OSCAR dataset for both the Global Ocean and the Antarctic Circumpolar Current region. Bias has to be intended as observed value minus model value.

\section{A satellite-based correction of precipitation fluxes}

A. Storto et al.

\section{Title Page}

Abstract

Introduction

Conclusions

References

Tables

Figures

14

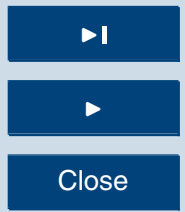

Back

Close

\section{Full Screen / Esc}

Printer-friendly Version

Interactive Discussion 


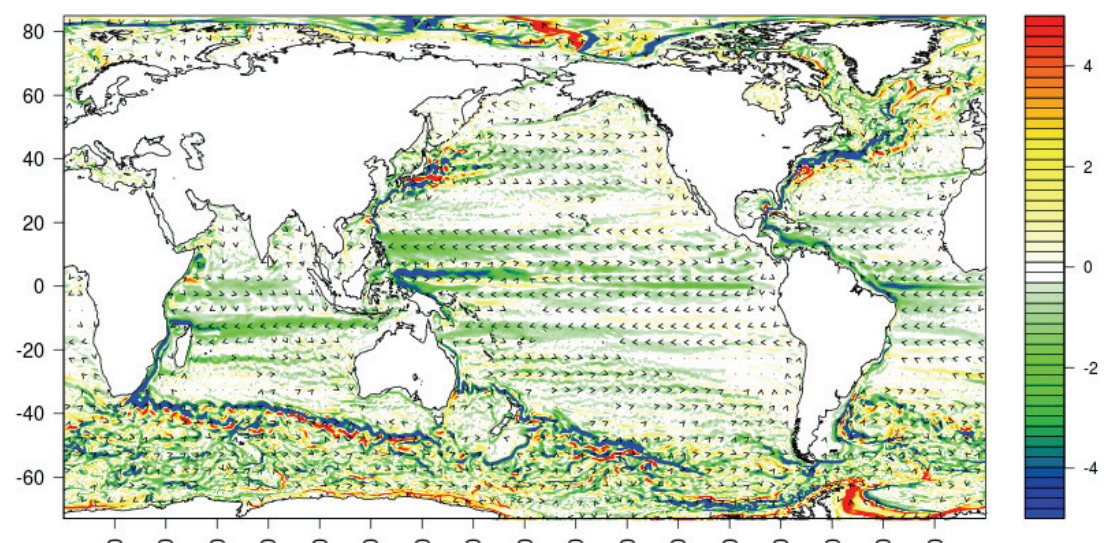

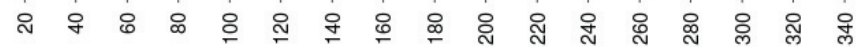

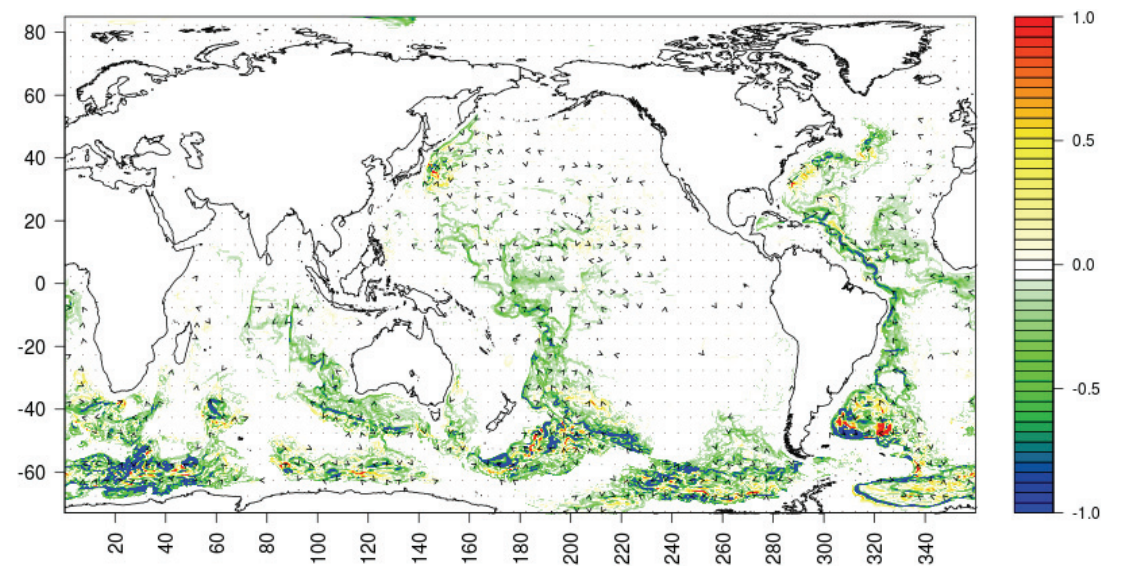

Fig. 10. Current speed differences (shaded contours) in $\mathrm{cm} \mathrm{s}^{-1}$ between the two experiments with and without the use of the precipitation correction and mean current direction (arrays) when the correction is used for surface $(0-100 \mathrm{~m}$, top panel) and bottom waters $(4000 \mathrm{~m}$-bottom, bottom panel).

Title Page

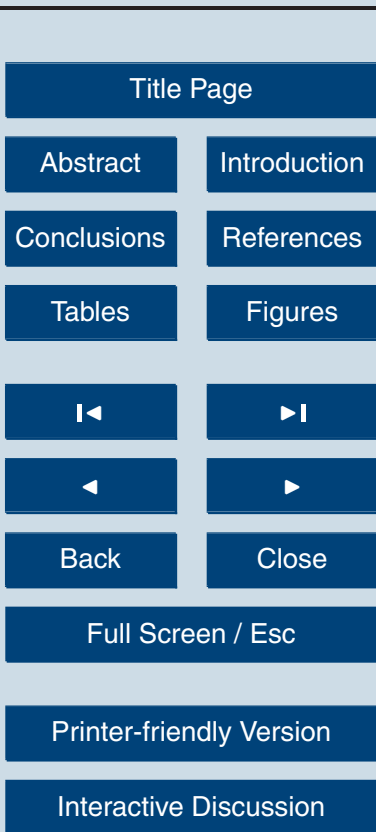

Printer-friendly Version

\section{A satellite-based correction of precipitation fluxes}

A. Storto et al.

Interactive Discussion 
Mean Meridional Freshwater Transport 1989-2009 GLOBAL OCEAN

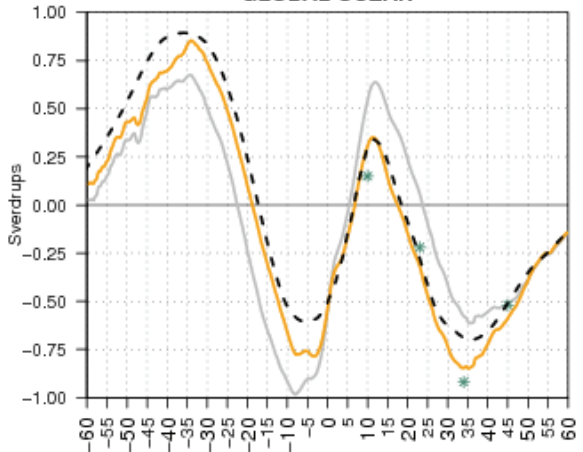

Mean Meridional Freshwater Transport 1989-2009 PACIFIC OCEAN

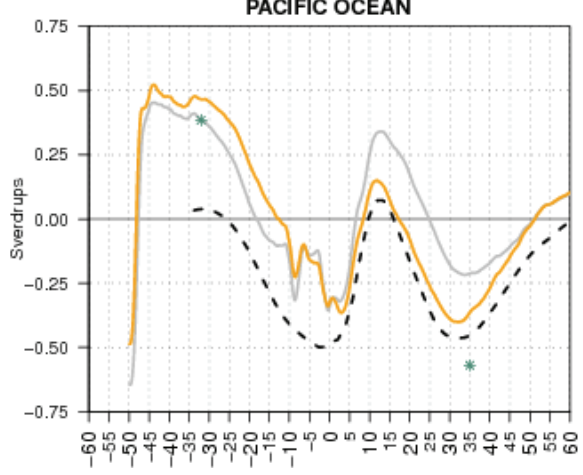

Mean Meridional Freshwater Transport 1989-2009 ATLANTIC OCEAN

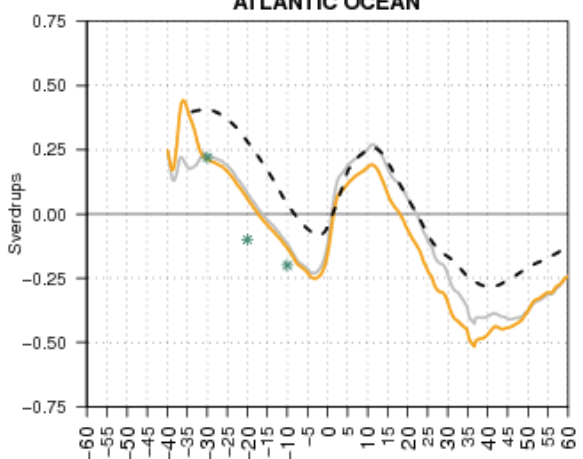

Mean Meridional Freshwater Transport 1989-2009 INDIAN OCEAN

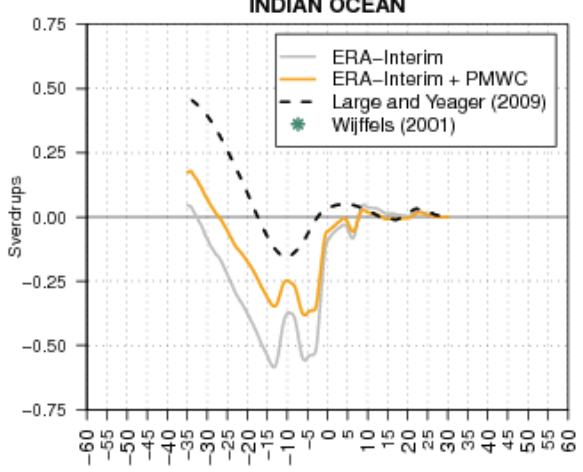

Fig. 11. Mean zonally averaged meridional freshwater transport for the Global, Atlantic, Pacific and Indian Ocean for the two experiments with and without the correction to the precipitation fluxes. Also are reported the estimates calculated by Large and Yeager (2009) through atmospheric reanalyses processing, and the estimation by Wijffels (2001) from hydrographic observations. 
Meridional Velocity

$(\mathrm{cm} / \mathrm{s})$

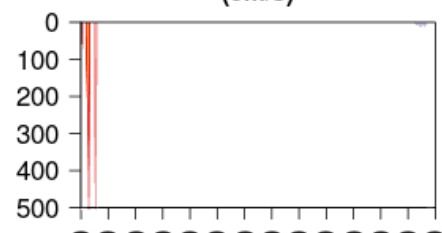

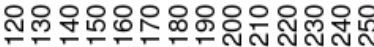

Meridional Velocity Difference $(\mathrm{cm} / \mathrm{s})$

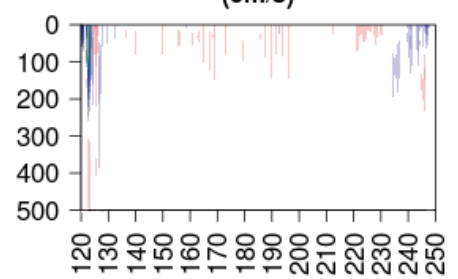

Sea-surface height (m)

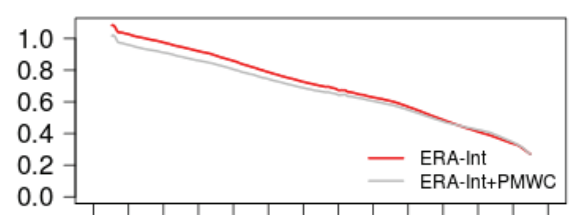

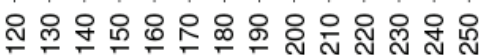

Salinity Anomaly

(PSU)
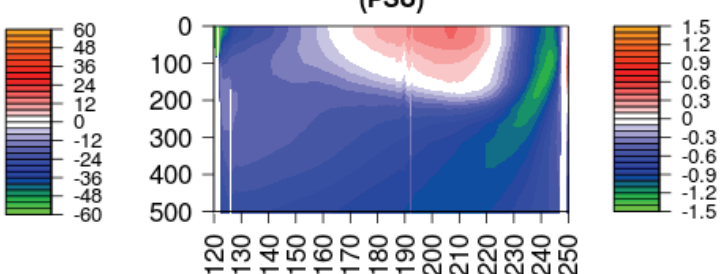

Salinity Anomaly

(PSU)

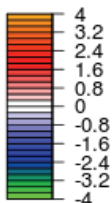

0
100
200
300
$400-$
500

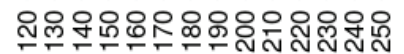

Meridional Freshwater Difference (10E-3 m3/s)

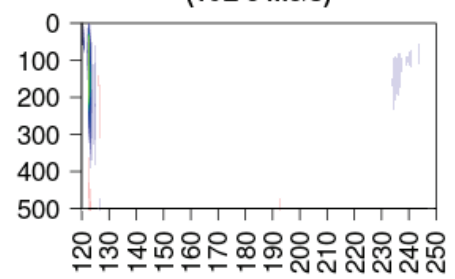

Fig. 12. Cross-sections of mean meridional velocity, mean difference between the meridional velocities of the experiments with and without the correction, mean salinity anomaly (salinity minus $35 \mathrm{psu}$ ) for the two experiment without and with the correction, mean difference of meridional freshwater transport and mean $\mathrm{SSH}$ at $25^{\circ} \mathrm{N}$ in the Pacific Ocean. $X$-axis values report degrees east; $y$-axis values report depth in meters, except for the mean SSH plot.

OSD

9, 611-648, 2012

\section{A satellite-based correction of precipitation fluxes}

A. Storto et al.

\section{Title Page}

Abstract

Introduction

Conclusions

References

Tables

Figures

14

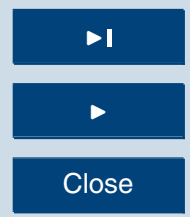

Back

Close

\section{Full Screen / Esc}

Printer-friendly Version

Interactive Discussion 